3

4

5

6

7

\title{
Cocoa agroforest multifunctionality and soil fertility explained by shade tree litter traits
}

Marie Sauvadet ${ }^{{ }^{*}}$, Stéphane Saj ${ }^{2,3}$, Grégoire T. Freschet ${ }^{4,5}$, Jean-Daniel Essobo ${ }^{6}$, Séguy Enock ${ }^{6}$, Thierry Becquer $^{1}$, Philippe Tixier ${ }^{7,8}$ \& Jean-Michel Harmand ${ }^{1,6,9}$

${ }^{1}$ Eco\&Sols, Univ Montpellier, IRD, INRA, CIRAD, Montpellier SupAgro, Montpellier, France

${ }^{2}$ System, Univ Montpellier, CIRAD, INRA, Montpellier SupAgro, Kourou, France

${ }^{3}$ CIRAD, UMR System, Montpellier, France

${ }^{4}$ Centre d'Ecologie Fonctionnelle et Evolutive, CNRS, Université de Montpellier, Université Paul Valéry Montpellier, EPHE, IRD, Montpellier, France

${ }^{5}$ Theoretical and Experimental Ecology Station, CNRS, Paul Sabatier University, Moulis, France

${ }^{6}$ World Agroforestry (ICRAF), West and Central Africa Regional Program, Yaounde, Cameroon

${ }^{7}$ GECO, Univ Montpellier, CIRAD, Montpellier, France

${ }^{8}$ CIRAD, UPR GECO, Montpellier, France

${ }^{9}$ CIRAD, UMR Eco\&Sols, Yaoundé, Cameroun

Corresponding author: Marie Sauvadet, IRD, UMR Eco\&Sols, 2 Place Pierre Viala, F-34060 Montpellier, France

Email:sauvadem@gmail.com

*Present address: Department of Physical and Environmental Science, University of Toronto Scarborough, Toronto, Canada 


\section{Abstract}

1. Manipulating plant functional diversity to improve agroecosystem multifunctionality is a central challenge of agricultural systems worldwide. In cocoa agroforestry systems (cAFS), shade trees are used to supply many services to farmers, yet their impact on soil functioning and cocoa yields is likely to vary substantially among tree species.

2. Here, we compared the impact of five shade tree species (Canarium schweinfurthii (Canarium), Dacryoides edulis (Safou), Milicia excelsa (Iroko), Ceiba pentandra (Kapok tree), Albizia adianthifolia (Albizia)) and unshaded conditions on the functioning of poor sandy savannah soils within eight cocoa farms in Central Cameroon. We assessed the effects of plant functional traits, leaf litterfall and fine root biomass on a range of soil functions and on cocoa yield.

3. Shade trees generally improved soil $\mathrm{pH}, \mathrm{NH}_{4}{ }^{+}, \mathrm{NO}_{3}{ }^{-}$and Olsen $\mathrm{P}$ content, biomass production of bioassays, and soil total $\mathrm{C}$ and $\mathrm{N}$ content, while leaving cocoa yields unchanged. However, these effects varied largely among species. Improvements of soil functions were low under the two fruit trees (Canarium and Dacryodes), medium under the legume tree Albizia, and high under the two timber trees (Milicia and Ceiba). Low litter recalcitrance was most strongly associated with increases in soil fertility indicators such as $\mathrm{N}$ and $\mathrm{P}$ availability, whereas soil $\mathrm{C}$ and $\mathrm{N}$ content increased with litter Ca restitution.

4. Synthesis and applications. We demonstrate that cocoa agroforest multifunctionality is substantially influenced by the functional traits of shade tree species. Shade tree species with the most dissimilar traits to cocoa (cocoa showing the lowest leaf litter quality) showed the largest improvement of soil functions. Therefore, selection of shade trees based on their functional traits appears as a promising practice to adequately manage soil functioning. In order to fully assess the beneficial role of shade trees in these agroecosystems, future research will need to extend this approach to other belowground traits and other aspects of multifunctionality such as long-term cocoa health and yield.

Keywords: agroecosystem multifunctionality, agroforestry, litter recalcitrance, cacao tree, fertility, plant functional traits, shade type, soil functions 


\section{French abstract}

1. Manipuler la diversité fonctionnelle végétale pour améliorer la multifonctionnalité des agroécosystèmes est un défi majeur à l'échelle mondiale. Dans les systèmes agroforestiers à base de cacaoyers, les arbres d'ombrage sont utilisés pour fournir de nombreux services aux agriculteurs. Cependant, leur impact sur le fonctionnement du sol et le rendement des cacaoyers est susceptible de varier considérablement d'une espèce à l'autre.

2. Nous avons comparé les effets de cinq espèces d'arbres d'ombrage (Canarium schweinfurthii (Canarium), Dacryoides edulis (Safoutier), Milicia excelsa (Iroko), Ceiba pentandra (Fromager ou Kapokier), Albizia adianthifolia (Albizia d'Afrique de l'Ouest) et d'un témoin sans arbres sur le fonctionnement du sol dans huit exploitations cacaoyères sur sol pauvre au Centre du Cameroun. Nous avons ensuite relié les traits fonctionnels des arbres et des litières aériennes ainsi que la biomasse de racines fines à plusieurs fonctions du sol et au rendement des cacaoyers.

3. Les arbres d'ombrage ont globalement amélioré le $\mathrm{pH}$, les teneurs en $\mathrm{NH}_{4}{ }^{+}, \mathrm{NO}_{3}{ }^{-}, \mathrm{P}$ Olsen, Carbone et Azote totaux du sol, et les biomasses produites en bioessais, tout en maintenant les rendements de cacao. Toutefois, ces effets ont considérablement varié d'une espèce à l'autre. Ces améliorations étaient de faible amplitude sous les deux arbres fruitiers (Canarium et Dacryodes), moyennes sous la légumineuse Albizia et élevées sous les deux arbres de bois d'œuvre (Milicia et Ceiba). La faible récalcitrance des litières aériennes a été associée à l'amélioration de la biodisponibilité en $\mathrm{N}$ et $\mathrm{P}$ du sol, tandis que les teneurs en $\mathrm{C}$ et $\mathrm{N}$ totaux du sol ont augmenté avec la quantité de Ca restituée par les litières aériennes.

4. Synthèse et applications. Nous démontrons que la multifonctionnalité des systèmes agroforestiers à base de cacaoyers est fortement liée aux traits fonctionnels des espèces d'arbres d'ombrage qui les composent. Les espèces d'ombrage présentant les traits les plus dissemblables des cacaoyers (les cacaoyers présentant la qualité de litière aérienne la plus faible) améliorent davantage la multifonctionnalité du sol que les autres espèces. La sélection des arbres d'ombrage basé sur leurs traits fonctionnels apparaît donc comme une pratique prometteuse pour améliorer le fonctionnement du sol. Afin d'évaluer pleinement le rôle bénéfique des arbres d'ombrage sur ces agroécosystèmes, les futures recherches devront 

multifonctionnalité, telles que la santé et le rendement à long terme des cacaoyers. 


\section{Introduction}

Ecosystems are expected to provide multiple functions and services for human society. Hence, ecosystems' health is now mainly assessed through their multifunctionality (Maestre et al., 2012; Wagg et al., 2014). Ecosystem multifunctionality is assumed to be maintained with high levels of aboveground and belowground biodiversity (Delgado-Baquerizo et al., 2016). However, the identity of species that live in the ecosystem, as well as their functional traits (defined as any morphological, physiological or phenological feature measurable at the individual level; Violle et al., 2007), are at least as important as biodiversity per se in explaining the effects of species richness on ecosystem multifunctionality (Peltzer et al., 2009; Maire et al., 2018). In the agricultural sector, stakeholders and managers are increasingly considering the identity of species that are associated with the crop, and their functional traits, in order to improve agroecosystem multifunctionality (Martin \& Isaac, 2015, 2018). For instance, Blesh (2018) recently found that cover crop mixtures with complementary functional traits increased multifunctionality. Likewise, Damour, Navas, \& Garnier (2018) proposed a trait-based approach framework which uses traits to select optimal plant community compositions and design agroecological cropping systems. While the use of plant functional traits to improve agroecosystems multifunctionality have been conceptualized in several recent works, it has yet scarcely been put into practice in the field. Improving agroecosystems functioning through plant diversification mainly relies on gross functional classification as $\mathrm{N}$-fixing ability or rooting type (Martin \& Isaac 2015 and citations therein). Finer characterization of plants introduced within agroecosystems and their impact on services and disservices provision would bestow more mechanistic keys to improve plant community composition management.

Improving agroecosystem multifunctionality by managing plant community composition represents an opportunity to increase the yield in cocoa agroforests (cAFS) from West Africa, where $70 \%$ of world cocoa is produced. Farmers introduce shade trees in cAFS to provide an understory shade that reduces cocoa physiological stress, pest and diseases outbreaks (Andres et al., 2016). The shade tree species used in cAFS are very diverse and are selected both for their shade cover and for the provision of additional goods to local populations (firewood, fruit, timber, medicine), which may reach up to $60 \%$ of total cAFS plot revenue when adequately managed (Juhrbandt, 2010). Nonetheless, shade trees can decrease cocoa growth and yield because of light interception (Sanchez 1995). Yet, this potential disservice is not always observed (Wartenberg et al., 2019), and may be reduced in low fertility systems (Isaac et al., 2007a). These studies suggest that (i) in poor soils, soil fertility increase with shade tree 
introduction may compensate for their light interception effects on cocoa yield (Isaac et al., 2007a), and that (ii) these effects are expected to vary strongly with shade tree species (Wartenberg et al., 2019). In this context, testing whether differences among shade trees functional traits can affect cocoa yield and soil fertility while providing goods for farmers is of high interest.

Shade tree effects on cocoa yield, nutritional status and soil fertility has been studied both at the community (Blaser et al., 2017; Niether et al., 2019) and at the species level (Isaac, Timmer, \& QuashieSam, 2007b; Wartenberg et al., 2019). Depending on the study, observed effects are explained by a variety of individual or community properties such as aboveground biomass (Isaac, Timmer, \& QuashieSam, 2007b; Niether et al., 2019; Wartenberg et al., 2019), leaf biomass nutrient concentration (Isaac, Timmer, \& Quashie-Sam, 2007b; Wartenberg et al., 2019) or canopy architecture and/or cover (Isaac, Timmer, \& Quashie-Sam, 2007b; Blaser et al., 2017; Wartenberg et al., 2019). Nonetheless, to our knowledge, there is no study considering the specific relationships between shade tree functional traits and agroecosystem functioning in CAFS. Studies on natural ecosystems underline positive relationships between leaf litter N, P and Ca concentrations and soil nutrient availability (Hobbie, 2015), whereas soil C storage may mostly depend on plant belowground traits such as root biomass, length, or mycorrhizal associations (Clemmensen et al., 2013; DuPont et al., 2014). However, whether the theoretical expectations that the traits of shade trees could be directly used to select for trees promoting greater CAFS multifunctionality remains to be tested.

We aim to determine whether shade tree traits could be used to identify the shade tree species with the highest improvement of cAFS multifunctionality components compared with unshaded cocoa. We first hypothesize that shades trees promote cAFS multifunctionality through increase of soil nutrient availability, C storage and goods production. We then hypothesize that soil nutrient availability and C content are positively influenced by shade trees' leaf litter nutrient concentration and root biomass, respectively.

\section{Materials and methods}

\subsection{Site description and experimental design}

The study was conducted in cocoa farms previously studied by Nijmeijer et al. (2019), in the villages of Bakoa and Guéfigué, in the Bokito district $\left(4^{\circ} 30 \mathrm{~N}, 11^{\circ} 10 \mathrm{E}\right)$ of Cameroon. This site is located in a forestsavannah transition zone, in a hilly area with gentle slopes at an altitude between 400 and $550 \mathrm{~m}$ a.s.l. Yearly average temperature is of $25^{\circ} \mathrm{C}$, with annual rainfall between 1300 and $1400 \mathrm{~mm}$ and a main dry 
season between November and March (Jagoret et al., 2012). Eight farms growing Theobroma cacao were selected, all established between 1950 and 2000 on savannah and located downhill. The eight farms selected were on Orthic Ferrasol, with similar soil texture (approx. $12 \%$ clay, $17 \%$ silt and $71 \%$ sand).

We chose five associated shade tree species, with contrasting characteristics and uses, regularly occurring in these agroecosystems: Canarium schweinfurthii and Dacryodes edulis (fruit trees, evergreen), Milicia excelsa and Ceiba pentandra (timber trees, deciduous), and Albizia adianthifolia $\left(\mathrm{N}_{2^{-}}\right.$ fixing tree, deciduous). Individuals of each shade tree species were selected within the eight farms in order to assess (i) their individual attributes and (ii) cocoa yield and soil functions under their canopy. Since the farms presented different tree species diversities, not all five species could be studied in each farm, resulting in a slightly unbalanced replication scheme. One individual tree by farm could be sampled for Dacryodes and Ceiba, whereas only seven, five and three individuals could be sampled across all eight farms for Milicia, Canarium and Albizia, respectively (see Table S1 for more details). For each shade tree individual, a subplot of $10 \mathrm{~m} \times 10 \mathrm{~m}$ was defined beneath the canopy in order to estimate maximum cocoa yield and to sample soil. In each of the eight cocoa farms, we also selected one subplot of cocoa trees $(10 \mathrm{~m} \times 10 \mathrm{~m})$ away from the canopy of any shade tree (at least at a distance corresponding to the height of the nearest shade tree, i.e. between $17 \mathrm{~m}$ and $45 \mathrm{~m}$ ), as the reference treatment (called "unshaded"). Cocoa density was on average $14 \pm 3$ cocoa $100 \mathrm{~m}^{-2}$ across all the sampled subplots and did not differ between treatments (Table 2).

\subsection{Soil sampling and analyses}

One composite sample of the $0-10 \mathrm{~cm}$ soil layer (2 $\mathrm{kg}$ dry soil) was prepared in May 2017 in each $10 \times 10 \mathrm{~m}$ subplot, at intermediate distance between the shade tree trunk and its canopy edge, and from 10 locations always situated $1 \mathrm{~m}$ away from the base of cocoa trunks. Because only three Albizia trees were found across the eight farms, two composite samples were taken beneath each tree of this species (for a total of six sub-samples).

Fresh, coarsely crumbled soil was used for a greenhouse plant bioassay in order to provide a general index of "soil biochemical fertility" of the ecosystem. According to Dybzinski et al. (2008), the greenhouse plant bioassay is an off-site assessment of soil fertility, relying on a short-term growth of seedlings of a model plant in soils collected beneath plant communities. Biomass production of the model plant in this controlled environment is considered as a direct response to soil fertility. Plant bioassay is thus only 
influenced by soil properties, while cocoa yield (also measured in this study) results from specific interactions between climate, soil, pest and disease pressure, shade trees, and the structure of the cocoa stand. In our study, maize was chosen as the bioassay model plant for its short-term sensitivity to soil nutrient limitations, as shown by Sauvadet et al. (2019). Briefly, 2-L pots were filled with $1.4 \mathrm{~kg}$ of soil at water holding capacity from each composite soil sample. Each pot was then sown with four seeds of maize (Zea mays L.) cv. CIRAD 412; only two plants were left in each pot after sprouting of the seeds. Maize seedlings were grown in a greenhouse $\left(25^{\circ} \mathrm{C}\right.$ average temperature, $81 \%$ average humidity) with manual watering to maintain soil at its water holding capacity. After 45 days of vegetative growth, shoots and roots of the plants were harvested, washed, dried at $65^{\circ} \mathrm{C}$, and weighed to obtain the above- and below-ground dry biomasses. Fresh, coarsely crumbled soil was also used for the measurement of soil inorganic $\mathrm{N}$ content. After extraction from $5 \mathrm{~g}$ (dry weight) of fresh soil, with $20 \mathrm{~mL}$ of a $1 \mathrm{M} \mathrm{KCl}$ solution, $\mathrm{NO}_{3}{ }^{-}$and $\mathrm{NH}_{4}{ }^{+}$were determined by continuous flow colorimetry (TRAACS 2000, Bran and Luebbe, Norderstedt, Germany).

After thorough mixing of the remaining soil, an aliquot of about $260 \mathrm{~g}$ (dry weight) of soil was sieved at $2 \mathrm{~mm}$ and air-dried before analysis of total $\mathrm{C}$, total $\mathrm{N}$, Olsen $\mathrm{P}, \mathrm{pH}\left(\mathrm{H}_{2} \mathrm{O}\right)$ and basal $\mathrm{C}$ and $\mathrm{N}$ mineralization. Total soil organic $\mathrm{C}$ and $\mathrm{N}$ were determined by dry combustion of dry soil subsamples ground to $0.2 \mathrm{~mm}$, using a CHN microanalyzer (Carlo Erba NA 2000). Soil pH $\left(\mathrm{H}_{2} \mathrm{O}\right)$ was determined by mixing $2 \mathrm{~g}$ of dry soil with $10 \mathrm{~mL}$ of deionized water for $30 \mathrm{~min}$. Olsen $\mathrm{P}$ content was measured after Olsen et al. (1954). Briefly, $250 \mathrm{mg}$ of dry soil were extracted with $5 \mathrm{~mL}$ of $0.5 \mathrm{M} \mathrm{NaHCO}_{3}$ at pH 8.5 by 30 min shaking. The $P$ within the extract was then measured according to the malachite green method (Rao et al., 1997). To measure soil C basal mineralization and nitrification, two aliquots of respectively $10 \mathrm{~g}$ and $25 \mathrm{~g}$ of dry soil were put in sealed jars after fixing their water content at a potential of pF 2.5 at $193 \mathrm{~g} \mathrm{H}_{2} \mathrm{O} \mathrm{kg}{ }^{-1}$ soil, then pre-incubated for one week at $20^{\circ} \mathrm{C}$. At the end of the pre-incubation, $\mathrm{NO}_{3}^{-}$was extracted from the $10 \mathrm{~g}$ dry soil aliquot with $40 \mathrm{~mL} 1 \mathrm{M} \mathrm{KCl}$, as the initial $\mathrm{NO}_{3}{ }^{-}$content. Jars containing the $25 \mathrm{~g}$ dry soil aliquot were then incubated at $28^{\circ} \mathrm{C}$ for 28 days with an alkali trap $(15 \mathrm{~mL}$ of $0.5 \mathrm{M}$ $\mathrm{NaOH}$ ). The traps were changed at 7, 14 and 28 days and analyzed for carbonates within the day. The remaining $\mathrm{NaOH}$ was titrated with $1 \mathrm{M} \mathrm{HCl}$. The final soil $\mathrm{NO}_{3}{ }^{-}$was assessed after 28 days of incubation at $28^{\circ} \mathrm{C}$ of the $25 \mathrm{~g}$ jars in the same way. 
Main attributes of individual shade trees and cocoa trees were characterized between August 2017 and March 2018. Succession guild, leaf habit and legume vs non-legume were documented after Saj et al. (2017a). Tree height was estimated using a rangefinder (TRUPULSE 360, Laser Technology Inc) for shade trees and a graduated stick for cocoa trees. Average crown diameter of each shade tree was estimated from four measurements of crown diameter done in cardinal and intercardinal directions $(\mathrm{N}$ S, E-O, NO-SE, NE-SO) using a compass and a tape decameter, and canopy area was calculated accordingly. Diameter at breast height (DBH) of cocoa and shade trees was measured using a diameter tape. As differences in cocoa attributes (cocoa height, leaf nutrient content) between unshaded and shaded cocoa were not significant (data not shown), only unshaded cocoa attributes were considered.

For all subplots, fine roots (diameter $<1 \mathrm{~cm}$ ) were sampled in March 2018 in the 0-10 cm layer near each soil sampling location, using an $8 \mathrm{~cm}$ diameter root auger. Roots from each sampling point were washed, sorted out manually by species (cocoa vs. shade tree), dried for one week at $37^{\circ} \mathrm{C}$, and weighed separately. Leaf litterfall was measured during 8 months (including the dry season) when most of the annual litterfall occurs (Nijmeier et al., 2019). Briefly, one $0.45 \mathrm{~m}^{2}$ collector was placed above each soil and fine roots sampling location of each subplot. Leaf litter was collected every 15 days between September 2017 and March 2018 and dried at $37^{\circ} \mathrm{C}$ for one week. For each collector and sampling date, dry weight of the collected litter was measured by species, then summed through all the sampling period.

Cocoa estimated maximum yield was assessed according to Saj et al. (2017b), by counting every 7 weeks the number of pods on all the cocoa plants of every $10 \times 10 \mathrm{~m}$ subplots, between June and December 2017 (four campaigns).

\subsection{Leaf litter traits}

Leaf litter collected from each litterfall collector was then used to measure C, N, P, Ca, Mg, K and tannin content, Van Soest fractions and $\mathrm{pH}\left(\mathrm{H}_{2} \mathrm{O}\right)$. In order to have enough material to retain three replicates by species, $1.5 \mathrm{~g}$ composite samples were made by pooling the litter across the farms with the closest proximity (see Table S1 for further details).

Total $\mathrm{C}$ and $\mathrm{N}$ contents were determined by dry combustion using a $\mathrm{CHN}$ micro-analyzer (Carlo Erba NA 2000). After acid extraction, $\mathrm{Ca}, \mathrm{Mg}$, and $\mathrm{K}$ contents were determined by atomic absorption spectroscopy. Litter P content was analyzed using Murphy and Riley reagent, and readings were done by colorimetry. Water-soluble compounds, hemicellulose, cellulose and lignin contents were obtained 
by the van Soest method (Van Soest, 1963) with a Fibersac 24 fiber analyser (Ankom, Macedon, NJ, USA). Condensed tannins were measured according to the acid butanol method (Coq et al. 2010). For $\mathrm{pH}, 0.15 \mathrm{~mL}$ of each ground sample was shaken with $1.2 \mathrm{~mL}$ demineralized water in an Eppendorf tube for $1 \mathrm{~h}$ at $250 \mathrm{rpm}$. After centrifugation at $9000 \mathrm{~g}$ for $5 \mathrm{~min}, \mathrm{pH}$ of the supernatant solution was measured (Cornelissen et al., 2006). Lignocellulose Index (van Soest lignin / [van Soest hemicellulose + cellulose + lignin]) and Lignin: $\mathrm{N}$ ratio (van Soest lignin / leaf litter $\mathrm{N}$ content) were calculated.

Leaf $\mathrm{N}$ and $\mathrm{P}$ resorption efficiencies were estimated as described by Freschet et al. (2010), by measuring the proportional difference between green leaves (collected from the crown of each shade tree and from cocoa plants in each unshaded area in October 2017) and leaf litter nutrient content. This ratio wascorrected for fractional change in the measurement basis using lignin content as a reference value (Freschet et al., 2010).

\subsection{Data analyses}

Litterfall and soil properties data from Albizia pseudo-replicates were averaged under each Albizia tree (i.e. one value by tree) for all the subsequent statistical analyses. In order to understand the impacts of cocoa - shade tree associations on CAFS functions, we first calculated the community weighted mean (CWM) leaf litter trait values above each soil sampling location, according to the formula (1):

$\mathrm{CWM}_{\mathrm{x}}=\mathrm{p}_{\text {cocoa }} \times \mathrm{t}_{\text {cocoa }}+\mathrm{p}_{\text {shade }} \times \mathrm{t}_{\text {shade }}$

where $\mathrm{CWM}_{\mathrm{x}}$ is the CWM for trait $\mathrm{x}, \mathrm{p}$ is the relative proportion of either cocoa or shade tree to the total leaf litterfall collected above each soil sampling location, and $t$ is the leaf litter trait value for cocoa or shade tree for the corresponding location (Table S1). We first confirmed with linear mixed-effects models that there were no farm (replicate) effects on CWM traits and soil functions (Table S3 and Table S4). CWM traits and soil functions differences between cocoa - shade tree associations were then assessed with generalized linear models coupled with the post hoc HSD Tukey tests. Finally, CWM traits were drawn in Principal Component Analyses (PCAs) in order to differentiate the main characteristics of cocoa-shade tree associations between the studied species. These analyses, coupled with Pearson correlation matrix (Figure S2), allowed to select the most pertinent CWM traits to explain soil functions in the subsequent analyses.

We considered the following agroecosystem functions: total soil organic $\mathrm{C}$, total $\mathrm{N}, \mathrm{NO}_{3}{ }^{-}, \mathrm{NH}_{4}{ }^{+}$, Olsen $\mathrm{P}$ content, soil pH, C mineralization, nitrification, bioassay, cocoa yield, as well as the type of production 
by shade trees: fruit or timber. An agroecosystem multifunctionality index was calculated under each treatment. Briefly, values of each function were standardized by its maximum across all treatments, and thus ranged between 0 and $100 \%$. Multifunctionality was then defined as the number of standardized functions under each cocoa - shade tree association that had a value above a threshold $\mathrm{T}(30,50,70$ and $90 \%$ ). C mineralization, which is considered as a negative process relative to cAFS functioning, was inverted before being standardized. Fruit and timber production were either attributed a value of 0 (non-producing) or $100 \%$ (producing) under a given shade tree species (Figure S1).

Beforehand analyses showed that soil functions under cocoa - shade tree associations were better explained with CWM litter traits than tree height and DBH. Only CWM litter traits were hence used to assess the associations impact on soil functions, with two complementary analyses. First, a redundancy analysis (RDA) was performed in order to visualize the global trends between the two sets of variables (the observed relationships between soil parameters and litter CWM were mostly linear, supporting the use of RDA). In a second time, each soil function responding significantly to shading was then regressed with all CWM traits. For each function, regression models were calculated with the dredge function from \{MuMIn\} R package. The parameters of the most parsimonious models (with lowest Akaike's information criterion; delta $<2$ ) were then used to calculate the relative importance $(\mathrm{RI})$ of each trait using the model.averaging function \{MuMIn\} R package (Giam and Olden, 2016). The model averaging approach provides synthetic information on which functional traits contribute most consistently to the models with lowest AICs, making them the most likely contributors to the ecosystem function of interest. All statistical analyses were performed using R software (R-3.3.1) and the following packages: ggtern (Hamilton \& Ferry, 2018), Ime4 (Bates et al., 2015), multcomp (Hothorn, Bretz \& Westfall, 2008), MuMIn (Barton \& Barton, 2018), psych (Revelle, 2017), stats (R Core Team, 2018) and vegan (Oksanen et al., 2018).

\section{Results}

\subsection{Cocoa and shade tree characteristics}

Shade tree species characteristics differed significantly between each other and from Theobroma cacao. Among shade trees, Dacryodes was the smallest and the thinnest species, while Ceiba was the tallest and widest species (Table 1). Litter $\mathrm{N}$ and $\mathrm{P}$ contents were higher for the deciduous (Milicia, Ceiba and Albizia) than for the evergreen species (Canarium and Dacryodes), the latter being at the same level as cocoa. Cocoa had higher leaf $\mathrm{N}$ and $\mathrm{P}$ resorption efficiencies than shade trees (except for Dacryodes $\mathrm{N}$ resorption), and higher or similar litter $\mathrm{Mg}$ content and $\mathrm{pH}$. Litter from the evergreen trees had lower $\mathrm{pH}$ 
$(<6)$, higher tannin content and Lignin: $\mathrm{N}$ ratio than litter from the deciduous shade tree species (Table 1). Among the deciduous species, litter from $\mathrm{N}_{2}$-fixing Albizia had the highest $\mathrm{N}$ content, and the lowest lignin: $\mathrm{N}$ ratio, $\mathrm{Mg}$ and tannin contents.

Association with shade trees affected strongly leaf litterfall but did not modify patterns of fine roots biomass significantly (Table 2). Cocoa litterfall was decreased by half under shade trees, regardless of the shade species considered. Shade tree litterfall varied between species and ranged from 2.6 to $4.7 \mathrm{t}$ $\mathrm{DM} \mathrm{ha}^{-1}$ (Table 2). The total amount of litterfall was lower for unshaded cocoa and cocoa shaded with Canarium than for the other associations. Cocoa leaf litterfall amounted for only 21 to $36 \%$ of total leaf litterfall under shade trees (Table 2). As a result, community weighted mean litter traits in association were thus mostly driven by the characteristics of the shade tree species (Table S2).

Community weighted mean litter quality was improved in cocoa - deciduous species associations with increased litter $\mathrm{pH}$ and decreased lignin: $\mathrm{N}$ ratio (Figure 1a; Table S2), as well as increased litter $\mathrm{N}, \mathrm{P}$, $\mathrm{K}$, and $\mathrm{Ca}$ contents (with the steepest increase of Ca content with Ceiba and and $\mathrm{N}$ content with Albizia, Figure 1b; Table S2). Association with evergreen species decreased the averaged litter quality through an increase of tannin content and a decrease in litter pH and Mg content (Figure 1, Table S2).

\subsection{CAFS multifunctionality}

Shade trees greatly altered the agroecosystem functions linked to soil fertility. Soil $\mathrm{NO}_{3}{ }^{-}$and Olsen $\mathrm{P}$ content, and the biomass produced by the maize bioassay were significantly improved under the influence of deciduous trees (Table 3). Soil pH was only improved under Milicia and Ceiba, while soil under Albizia was acidified compared to the other associations (Table 3). Only association with Ceiba led to a significant increase in soil $\mathrm{C}$ and $\mathrm{N}$ contents. Overall, shade trees had relatively little impact on soil C mineralization, nitrification and cocoa yield.

Agroecosystem multifunctionality was higher under cocoa - shade tree associations than under unshaded cocoa, yet depended on the shade tree species and the threshold considered (Figure 2). These improvements were more obvious at the threshold value of $50 \%$, where multifunctionality index increased from 2 for unshaded cocoa, to 4 for associations with Dacryodes, 6 with Canarium and Albizia, and 8 for associations with the two timber trees. Higher multifunctionality under the deciduous trees as compared to unshaded cocoa corresponded to higher $\mathrm{NO}_{3}{ }^{-}$, Olsen $\mathrm{P}$ content and bioassay production, as well as the additional fruit or timber production of all shade trees except Albizia (Figure S1). Impacts 
of shade trees on multifunctionality decreased for higher threshold values (70 and $90 \%)$ and became null for Albizia relatively to unshaded cocoa. Multifunctionality improvement under the other shade trees at the $90 \%$ threshold corresponded respectively to edible fruit production under Canarium and Dacryodes, and to timber production and soil pH increase under Milicia and Ceiba (Figure 2 and S1).

\subsection{Relationships between cocoa - shade tree association characteristics and soil functions}

The model averaging and redundancy analyses both suggested that litter $\mathrm{N}, \mathrm{Ca}$, soluble and tannin content were among the most important contributors to the changes in soil functions (Figure 3a; Table 4). Cocoa association with the two timber species, Ceiba and Milicia, increased total litterfall, CWM litter $\mathrm{P}$ and $\mathrm{Ca}$ content, and were linked with higher soil $\mathrm{NO}_{3}{ }^{-}$, Olsen $\mathrm{P}$ content, bioassay production and soil $\mathrm{C}$ and $\mathrm{N}$ content (Figure 3). Cocoa association with Albizia led to litter $\mathrm{N}$ enrichment, linked to increased soil $\mathrm{NH}_{4}{ }^{+}$and $\mathrm{NO}_{3}{ }^{-}$content but also to a decrease of soil $\mathrm{pH}$. Association with evergreen Canarium and Dacryodes had limited effects both on CWM litter traits and agroecosystems functions changes from unshaded cocoa (Figure 3b). The model averaging approach highlighted most particularly the role of litter $\mathrm{Ca}$ content, which contributed to most of the soil functions considered $\left(\mathrm{RI}>0.64\right.$ for soil $\mathrm{C}, \mathrm{N}, \mathrm{NO}_{3}{ }^{-}$ content, soil pH and bioassay production). Further, litter tannin content was negatively associated with soil $\mathrm{NH}_{4}{ }^{+}$and Olsen $\mathrm{P}$ content ( $\mathrm{RI}$ of 0.96 and 0.76 , respectively), while litter soluble content was negatively associated with $\mathrm{NH}_{4}^{+}$and litter $\mathrm{N}, \mathrm{P}, \mathrm{K}$ and Ca were associated with soil $\mathrm{pH}$.

\section{Discussion}

Shade trees management in cocoa plantation has been discussed for decades regarding their benefits and disadvantages for cAFS (Sanchez, 1995; Andres et al., 2016; Blaser et al., 2017; Niether et al., 2019). The microclimatic regulation introduced by shading decreases diseases' outbreaks, which are known to hamper both cocoa yield and sustainability (Andres et al., 2016). However, light interception by shade trees decreases cocoa photosynthesis activity and may lead to yield decrease, as reviewed by Sanchez (1995). However, this decrease may not occur in systems with poor soils, where nutrient availability may be more limiting to cocoa production than light (Isaac et al., 2007a). Here, we demonstrated that several species of shade trees were able to improve contrasting aspects of soil fertility, without affecting cocoa yield. This result is in line with recent findings from Wartenberg et al. (2019). The five shade tree species studied generally improved nutrient restitution from litter, through increased litterfall and litter quality over the year, as compared with cocoa alone, and had positive effects 
on a range of soil functions linked to soil fertility. Together, these results suggest that the putative negative impact of shading has been compensated here by the relief of soil nutrient limitation for cocoa production and/or improved cocoa nutrient use efficiency under their canopy (Niether et al., 2019). The lack of increase in cocoa production under shade trees suggests nonetheless that light would have become a limiting resource, setting an upper threshold to the benefits of such improved soil nutrient conditions. Finally, our results suggest that, in places where soils are naturally poor or impoverished by decades of cocoa monocultures with low input levels, such as in Côte d'Ivoire or Ghana, the plantation of shade trees is likely to allow a gain in sustainability since positive effects on soil nutritional status would counterbalance the effects of competition for light.

The number of soil functions improved under cocoa - shade tree associations varied greatly between shade tree species, as driven by differences in litter quality. Shade tree litter constitutes indeed a significant source of organic matter inputs in most cAFS, with important effects on carbon and nutrient cycling (Nesper et al., 2019). This was particularly true in conditions of poor sandy soil. Out of all the parameters tested, CWM litter $\mathrm{Ca}$ and, to a lesser extent, tannin content had the highest explanatory weights for many soil functions. In our systems, these two litter traits, which typically drive litter decomposability and turnover rate in soils (Kraus, Dahlgren, \& Zasoski, 2003; Hobbie, 2015), proved to be of higher significance for soil fertility and $\mathrm{C}$ sequestration than classical indices of litter $\mathrm{N}$ and $\mathrm{P}$ content, amount of aboveground litterfall and belowground fine root biomass.

Associations with the evergreen fruit trees Canarium and Dacryodes led to the lowest improvement of soil functions compared to the unshaded reference. These were the species with the closest characteristics to cocoa (leaf life span strategy, litter nutrient content) and the lowest nutrient restitution levels by litterfall. Further, the high recalcitrance of Canarium and Dacryodes litters (high tannins content, low pH) may also have limited litter nutrient release and availability to plants due to their low turnover rate (Hättenschwiler et al., 2011; Hobbie, 2015). In contrast, the three deciduous tree species exhibited more contrasting properties compared to cocoa, and generally led to a more substantial improvement of soil fertility. More specifically, the increased soil $\mathrm{pH}$ induced by the associations with the deciduous timber tree species (Milicia and most particularly Ceiba), could be at least partly attributed to the higher amount of $\mathrm{Ca}$ and $\mathrm{Mg}$ restituted by their litter (Reich et al., 2005). In addition, Milicia is an oxalic species known to accumulate calcium carbonate in soil (Cailleau et al., 2005). In contrast, association with Albizia decreased soil pH to lower levels than cocoa alone. Soil acidification are often 
observed in legume plantations and could be caused by their $\mathrm{N}_{2}$-fixing activity (Jensen \& HauggaardNielsen, 2003). Soil pH decrease under legume can also result in soil P release (Hinsinger et al, 2003) and could be responsible to the high Olsen P content under Albizia associations. Finally, the positive impact of associations with deciduous species on soil $\mathrm{N}$ and $\mathrm{P}$ availability may be linked to the high quality of the deciduous species litters (low lignin: $\mathrm{N}$ ratio and tannin content) as much as to its high $\mathrm{N}$ and $\mathrm{P}$ content. Indeed, despite similar $\mathrm{N}$ and $\mathrm{P}$ content, litter from the evergreen tree Dacryodes, with lower overall quality, improved less soil $\mathrm{N}$ and $\mathrm{P}$ availability than the deciduous tree species.

Our finding that litter low recalcitrance is associated with higher soil $C$ sequestration is in line with the recent paradigm that plant species with rapid litter decomposition may be associated with relatively greater accumulation of soil C (Hobbie, 2015). However, this process may be hampered by soil acidification by legume $\mathrm{N}_{2}$-fixing activity in the case of Albizia association. Indeed, high litter Ca content generally favors litter consumption by soil fauna (Holdsworth, Frelich, \& Reich, 2008) which is increasingly considered as favoring soil C storage (Berg, 2000; 2014). Secondary transformations during the production of decomposer necromass and faeces favor organic matter mixing and binding with soil mineral matrix and hence its stabilization (Lehman and Rillig, 2015). Despite increasing recognition of the important role of fine root biomass and turnover in soil C storage (Clemmensen et al., 2013; DuPont et al., 2014), the similar fine-root biomass observed here could not explain the differences in soil C content. In order to adequately capture root carbon and nutrient inputs to the soil (Matamala et al. 2003), further studies will need to go beyond classical measurements of standing biomass and to focus more specifically on root turnover, exudation rates and mycorrhizal associations.

Overall, cocoa - Ceiba was the association that increased most cAFS multifunctionality, along with cocoa - Milicia associations. Litter from these shade tree species were both characterized by high Ca restitution levels in litterfall and low litter recalcitrance, and presented overall the highest level of dissimilarity with cocoa litter. This trend may suggest that shade trees that differ most from cocoa may provide stronger benefits in CAFS. In a context where tree species should be selected for (i) the desired shade cover and production of goods for local population, with (ii) traits favoring soil multifunctionality

411 (i.e. low litter recalcitrance and high nutrient content), our results suggest that the selection of a small number of tree species may provide better results than including a large range of species. Nonetheless, multifunctionality in our study was mainly centered on soil functions. The relative importance of other goods provision for local population, including timber and fruit, should not be overlooked as they are 
valued by farmers (Jagoret et al., 2014) and may constitute a fair share of total cAFS plot revenue when adequately managed (Juhrbandt, 2010). Furthermore, our results once again underline the empirical knowledge of farmers on the impact of their associations and the trade-offs they sometimes imply (Saj et al., 2017 a,b). In this respect, long-term studies integrating socio-economical aspects of cocoa and goods' production, together with soil fertility indicators are further needed to meaningfully attribute a weighting to each components of the agroecosystem functioning for profitable and sustainable management. Considering other benefits potentially associated with maintaining high tree diversity at the field scale, such as complementarity in resource use (Gross et al., 2017), stability of ecosystem functioning in conditions of climate change (Eisenhauer et al., 2018) and their resistance to perturbations (Loreau \& de Mazancourt, 2013) would also be useful.

\section{Conclusions}

Our study highlighted the benefits of introducing shade trees on agroecosystem multifunctionality on poor sandy soils, where the balance between lower light availability and higher soil nutrient availability maintain similar cocoa yield. Such benefits ranged from improved soil fertility to higher soil C sequestration. Nonetheless, multifunctionality improvement from unshaded cocoa strongly depended on the tree species, with lower effects of the evergreen fruit trees Canarium and Dacryodes, intermediate improvements by the legume tree Albizia, and strong improvement by the two timber trees Milicia and Ceiba. Our results suggest that the traits of some shade trees were too similar to these of cocoa to induce consistent change of soil functioning. High leaf litter $\mathrm{Ca}$ and low tannin contents of shade trees appeared particularly important to improve the local poor sandy soil conditions. These results underline the need to go beyond classical indicators of litter quality and soil functioning and the importance to consider aspects of long-term litter cycling in assessments of agroecosystem multifunctionality.

\section{Acknowledgments}

The present work was funded by the Agropolis foundation, STRADIV project ( $\left.\mathrm{n}^{\circ} 1504-003\right)$ and received some support from the BNP Paribas Foundation, SoCa project $\left(n^{\circ} 306735 / 00\right)$. This work was carried out within the framework of the CGIAR Research Program on Forests, Trees and Agroforestry (FTA). The authors thank Baba Gaspard and Shu Festus from ICRAF, Rose N'dango from IITA, Nancy Rakotondrazafy, Najat Talha, Joëlle Toucet, Jean Larvy-Delarivière, Jean-Marc Souquet from UMR Eco\&Sols and Yamei Chen from CEFE for their help with soil sampling and analyses. We are grateful 
445 to Michel Roux-Cuvelier from CIRAD - La Réunion for providing us the seeds for the maize bioassay 446 and IMAGO-LAMA lab (IRD, Dakar) for soil texture analyses. We are grateful to the editor and reviewer

447 for the many constructive comments on this manuscript.

448 Authors' contributions

449 All authors conceived the ideas and designed methodology; M.S., G.T.F., JD.E., S.E. and JM.H. 450 collected the data; M.S. analyzed the data; M.S., S.S., G.T.F., T.B., P.T. and JM.H. led the writing of the 451 manuscript. All authors contributed critically to drafts and gave final approval for publication.

452 Data availability statement

453 Data available via the Dryad Digital Repository https://doi.org/10.5061/dryad.dz08kprt6 (Sauvadet et al., 454 2019).

455 ORCID

456 Marie Sauvadet https://orcid.org/0000-0002-7520-8565

457 Stéphane Saj https://orcid.org/0000-0001-5856-5459

458 Grégoire T. Freschet https://orcid.org/0000-0002-8830-3860

459 Thierry Becquer https://orcid.org/0000-0001-5846-5810

460 Philippe Tixier https://orcid.org/0000-0001-5147-9777 


\section{References}

463 Andres, C., Comoé, H., Beerli, A., Schneider, M., Rist, S., \& Jacobi, J. (2016). Cocoa in monoculture and dynamic 464 agroforestry. In Lichtfous E. (eds) Sustainable Agriculture Reviews. Sustainable Agriculture Reviews, vol 19. 465 Springer, Cham.

466 Barton, K., Barton, M.K. (2018). Package 'MuMIn.' Multi-model inference. R package version 1.42 .1

467 Bates, D., Mächler, M., Bolker, B., Walker, S. (2015). Fitting Linear Mixed-Effects Models Using Ime4. Journal of 468 Statistical Software 67, 1-48.

469 Berg, B. (2000). Litter decomposition and organic matter turnover in northern forest soils. Forest Ecology and $470 \quad$ Management, 133, 13-22.

471 Berg, B. (2014). Decomposition patterns for foliar litter - A theory for influencing factors. Soil Biology and Biochemistry, $472 \quad 78,222-232$.

473 Blaser, W. J., Oppong, J., Yeboah, E., \& Six, J. (2017). Shade trees have limited benefits for soil fertility in cocoa $474 \quad$ agroforests. Agriculture, Ecosystems \& Environment 243, 83-91.

475 Blesh, J. (2018). Functional traits in cover crop mixtures: Biological nitrogen fixation and multifunctionality. Journal of $476 \quad$ Applied Ecology, 55, 38-48.

477 Cailleau, G., Braissant, O., Dupraz, C., Aragno, M., \& Verrecchia, E.P. (2005). Biologically induced accumulations of $478 \quad \mathrm{CaCO} 3$ in orthox soils of Biga, Ivory Coast. Catena, 59, 1-17.

479 Clemmensen, K. E., Bahr, A., Ovaskainen, O., Dahlberg, A., Ekblad, A., Wallander, H., Stenlid, J., Finlay, R. D., Wardle, 480 D. A., and Lindahl, B. D. (2013). Roots and Associated Fungi Drive Long-Term Carbon Sequestration in Boreal $481 \quad$ Forest. Science, 339, 1615-1618.

482 Coq, S., Souquet, J. M., Meudec, E., Cheynier, V., \& Hättenschwiler, S. (2010). Interspecific variation in leaf litter 483 tannins drives decomposition in a tropical rain forest of French Guiana. Ecology, 91, 2080-2091.

484 Cornelissen, J. H. C., Quested, H. M., van Logtestijn, R. S. P., Pérez-Harguindeguy, N., Gwynn-Jones, D., Díaz, S., 485 Callaghan, T.V., Press, M.C., and Aerts, R. (2006). Foliar pH as a new plant trait: can it explain variation in foliar $486 \quad$ chemistry and carbon cycling processes among subarctic plant species and types? Oecologia, 147, 315-326.

487 Damour, G., Navas, M. L., \& Garnier, E. (2018). A revised trait-based framework for agroecosystems including decision 488 rules. Journal of Applied Ecology, 55, 12-24.

489 Delgado-Baquerizo, M., Maestre, F. T., Reich, P. B., Jeffries, T. C., Gaitan, J. J., Encinar, D., Berdugo, M., Campbell, 490 C. D., and Singh, B. K. (2016). Microbial diversity drives multifunctionality in terrestrial ecosystems. Nature $491 \quad$ Communications, 7, 10541.

492 DuPont, S. T., Beniston, J., Glover, J. D., Hodson, A., Culman, S. W., Lal, R., \& Ferris, H. (2014). Root traits and soil 493 properties in harvested perennial grassland, annual wheat, and never-tilled annual wheat. Plant and Soil, 381, 494 405-420.

495 Dybzinski, R., Fargione, J. E., Zak, D. R., Fornara, D., \& Tilman, D. (2008). Soil fertility increases with plant species 496 diversity in a long-term biodiversity experiment. Oecologia, 158, 85-93.

497 Eisenhauer, N., Hines, J., Isbell, F., van der Plas, F., Hobbie, S. E., Kazanski, C. E., ..., Baldwin I.T. (2018). Plant 498 diversity maintains multiple soil functions in future environments. eLife, 7, e41228.

499 Freschet, G. T., Cornelissen, J. H. C., van Logtestijn, R. S. P., \& Aerts, R. (2010). Substantial nutrient resorption from 500 leaves, stems and roots in a subarctic flora: what is the link with other resource economics traits? New $501 \quad$ Phytologist, 186, 879-889.

502 Giam, X., \& Olden, J. D. (2016). Quantifying variable importance in a multimodel inference framework. Methods in $503 \quad$ Ecology and Evolution, 7, 388-397.

504 Gross, N., Bagousse-Pinguet, Y. L., Liancourt, P., Berdugo, M., Gotelli, N. J., \& Maestre, F. T. (2017). Functional trait 505 diversity maximizes ecosystem multifunctionality. Nature Ecology \& Evolution, 1, 0132.

506 Hamilton, N.E., Ferry, M. (2018). ggtern: Ternary Diagrams Using ggplot2. Journal of Statistical Software 87, 1-17.

507 Hättenschwiler, S., Coq, S., Barantal, S., \& Handa, I.T. (2011). Leaf traits and decomposition in tropical rainforests: 508 revisiting some commonly held views and towards a new hypothesis. New Phytologist, 189, 950-965.

509 Hinsinger, P., Plassard, C., Tang, C.X., \& Jaillard, B. (2003). Origin of root-mediated pH changes in the rhizosphere

510 and their responses to environmental constraints - a review. Plant and Soil, 248, 43-59.

511 Hobbie, S. E. (2015). Plant species effects on nutrient cycling: revisiting litter feedbacks. Trends in Ecology \& Evolution, 512 30, 357-363.

513 Holdsworth, A. R., Frelich, L. E., \& Reich, P. B. (2008). Litter decomposition in earthworm-invaded northern hardwood 514 forests: Role of invasion degree and litter chemistry. Ecoscience 15, 536-544.

515 Hothorn, T., Bretz, F., Westfall, P. (2008). Simultaneous inference in general parametric models. Biometrical Journal $51650,346-363$.

517 Isaac, M. E., Ulzen-Appiah, F., Timmer, V. R., \& Quashie-Sam, S. J. (2007a). Early growth and nutritional response to 518 resource competition in cocoa-shade intercropped systems. Plant and Soil, 298, 243-254.

519 Isaac, M. E., Timmer, V. R., and Quashie-Sam, S. J. (2007b). Shade tree effects in an 8-year-old cocoa agroforestry 520 system: biomass and nutrient diagnosis of Theobroma cacao by vector analysis. Nutrient Cycling in 521 Agroecosystems, 78, 155-165. 
522 Jagoret, P., Michel-Dounias, I., Snoeck, D., Ngnogué, H. T., and Malézieux, E. (2012). Afforestation of savannah with 523 cocoa agroforestry systems: a small-farmer innovation in central Cameroon. Agroforestry Systems, 86, 493524504.

525 Jagoret, P., Kwesseu, J., Messie, C., Michel-Dounias, I., \& Malézieux, E. (2014). Farmers' assessment of the use value 526 of agrobiodiversity in complex cocoa agroforestry systems in central Cameroon. Agroforestry Systems, 88, 983$527 \quad 1000$.

528 Jensen, E. S., \& Hauggaard-Nielsen, H. (2003). How can increased use of biological N2 fixation in agriculture benefit 529 the environment? Plant and Soil, 252, 177-186.

530 Juhrbandt, J., Duwe, T., Barkmann, J., Gerold, G., \& Marggraf, R. (2010). Structure and management of cocoa 531 agroforestry systems in Central Sulawesi across an intensification gradient. In Tropical Rainforests and 532 Agroforests under Global Change, (pp. 115-140). Berlin, Heidelberg, Germany: Springer.

533 Kraus, T. E. C., Dahlgren, R. A., \& Zasoski, R. J. (2003). Tannins in nutrient dynamics of forest ecosystems - a review. $534 \quad$ Plant and Soil, 256, 41-66.

535 Lehmann, A., \& Rillig, M. C. (2015). Understanding mechanisms of soil biota involvement in soil aggregation: A way 536 forward with saprobic fungi? Soil Biology and Biochemistry, 88, 298-302.

537 Loreau, M., \& Mazancourt, C. de (2013). Biodiversity and ecosystem stability: a synthesis of underlying mechanisms. $538 \quad$ Ecology Letters, 16, 106-115.

539 Maestre, F. T., Castillo-Monroy, A. P., Bowker, M. A., \& Ochoa-Hueso, R. (2012). Species richness effects on 540 ecosystem multifunctionality depend on evenness, composition and spatial pattern. Journal of Ecology, 100 , 541 317-330.

542 Maire E., Villéger S., Graham N. A. J., Hoey A. S., Cinner J., Ferse S. C. A., .., Mouillot D. (2018). Community-wide

543 scan identifies fish species associated with coral reef services across the Indo-Pacific. Proceedings of the Royal $544 \quad$ Society B: Biological Sciences, 285, 20181167.

545 Martin, A. R., \& Isaac, M. E. (2015). Plant functional traits in agroecosystems: a blueprint for research. Journal of $546 \quad$ Applied Ecology, 52, 1425-1435.

547 Martin, A. R., \& Isaac, M. E. (2018). Functional traits in agroecology: Advancing description and prediction in 548 agroecosystems. Journal of Applied Ecology, 55, 5-11.

549 Matamala, R., Gonzàlez-Meler, M. A., Jastrow, J. D., Norby, R. J., \& Schlesinger, W. H. (2003). Impacts of Fine Root $550 \quad$ Turnover on Forest NPP and Soil C Sequestration Potential. Science, 302, 1385-1387.

551 Nesper, M., Kueffer, C., Krishnan, S., Kushalappa, C. G., \& Ghazoul, J. (2019). Simplification of shade tree diversity 552 reduces nutrient cycling resilience in coffee agroforestry. Journal of Applied Ecology, 56, 119-131.

553 Niether, W., Schneidewind, U., Fuchs, M., Schneider, M., \& Armengot, L. (2019). Below- and aboveground production 554 in cocoa monocultures and agroforestry systems. Science of the Total Environment, 657, 558-567.

555 Nijmeijer, A., Lauri, P. E., Harmand, J. M., Freschet, G. T., Essobo Nieboukaho, J. D., Fogang, P. K., Enock, S., \& Saj,

556 S. (2019). Long-term dynamics of cocoa agroforestry systems established on lands previously occupied by 557 savannah or forests. Agriculture, Ecosystems \& Environment, 275, 100-111.

558 Oksanen, J., Blanchet, F.G., Friendly, M., Kindt, R., Legendre, P., McGlinn, D., Minchin, P.R., O'hara, R.B., Simpson, 559 G.L., Solymos, P. (2018). Vegan: Community Ecology Package, R package, version. 2.4-6.

560 Olsen, S. R., Sterling R. (1954). Estimation of available phosphorus in soils by extraction with sodium bicarbonate. 561 Washington, D.C.: U.S. Dept. of Agriculture.

562 Peltzer, D. A., Bellingham, P. J., Kurokawa, H., Walker, L. R., Wardle, D. A., \& Yeates, G. W. (2009). Punching above 563 their weight: low-biomass non-native plant species alter soil properties during primary succession. Oikos, 118, 564 1001-1014.

565 R Core Team (2018). R: A language and environment for statistical computing. R Foundation for Statistical Computing, $566 \quad$ Vienna, Austria.

567 Reich, P.B., Oleksyn, J., Modrzynski, J., Mrozinski, P., Hobbie, S.E., Eissenstat, D.M., Chorover, J., Chadwick, O.A., 568 Hale, C.M., Tjoelker, M.G. (2005). Linking litter calcium, earthworms and soil properties: a common garden test $569 \quad$ with 14 tree species. Ecology Letters, 8, 811-818.

570 Revelle, W.R. (2017). psych: Procedures for Personality and Psychological Research. R package, version 1.8.12.

571 Saj, S., Durot, C., Mvondo Sakouma, K., Tayo Gamo, K., \& Avana-Tientcheu, M. L. (2017a). Contribution of associated 572 trees to long-term species conservation, carbon storage and sustainability: A functional analysis of tree

573 communities in cacao plantations of Central Cameroon. International Journal of Agricultural Sustainability, 15, $574 \quad 282-302$.

575 Saj, S., Jagoret, P., Etoa, L. E., Eteckji Fonkeng, E., Tarla, J. N., Essobo Nieboukaho, J. D., \& Mvondo Sakouma, K. 576 (2017b). Lessons learned from the long-term analysis of cacao yield and stand structure in central Cameroonian 577 agroforestry systems. Agricultural Systems, 156, 95-104.

578 Sanchez, P. A. (1995). Science in agroforestry. Agroforestry Systems, 30, 5-55.

579 Sauvadet, M., Saj, S., Freschet, G., Essobo, J.-D., Enock, S., Becquer, T., Tixier, P. \& Harmand, J.-M. (2019), Data 580 from: Cocoa agroforest multifunctionality and soil fertility explained by shade tree litter, Dryad Digital 581 Repository, https://doi.org/10.5061/dryad.dz08kprt6 
582 Sauvadet, M., den Meersche, K.V., Allinne, C., Gay, F., de Melo Virginio Filho, E., Chauvat, M., Becquer, T., Tixier, P., 583 \& Harmand, J.-M. (2019). Shade trees have higher impact on soil nutrient availability and food web in organic 584 than conventional coffee agroforestry. Science of the Total Environment, 649, 1065-1074.

585 Van Soest, P. J. (1963). The use of detergents in the analysis of fibrous feeds. II. A rapid method for the determination 586 of fiber and lignin. Journal of the Association of Official Analytical Chemists, 829-835.

587 Wagg, C., Bender, S. F., Widmer, F., \& van der Heijden, M. G. A. (2014). Soil biodiversity and soil community 588 composition determine ecosystem multifunctionality. Proceedings of the National Academy of Sciences of the $589 \quad$ United States of America, 111, 5266-5270.

590 Violle, C., Navas, M.-L., Vile, D., Kazakou, E., Fortunel, C., Hummel, I., \& Garnier, E. (2007). Let the concept of trait 591 be functional! Oikos, 116, 882-892.

592 Wartenberg, A. C., Blaser, W. J., Roshetko, J. M., Van Noordwijk, M., \& Six, J. (2019). Soil fertility and Theobroma 593 cacao growth and productivity under commonly intercropped shade-tree species in Sulawesi, Indonesia. Plant 594 and Soil. 


\section{$595 \quad$ Figure captions}

596 FIGURE 1 Principal component analyses of (a) averaged leaf litter $\mathrm{C}$ quality and (b) leaf nutrient contents 597 and litterfall. Only variables significantly impacted by shade tree species are represented. NRE: leaf N 598 resorption efficiency; PRE: leaf P resorption efficiency; LCl: Litter lignocellulose Index; \%N, P, K, Ca, 599 Mg: leaf litter N, P, K, Ca, Mg content.

600

601 FIGURE 2 Shade tree association effects on soil multifunctionality. Each of the 12 functions tested were standardized by their maximal values, then compared to the threshold values of $0,30,50,70$ and $90 \%$.

603

604

FIGURE 3 Redundancy analysis of soil functions (in red) constrained by cocoa - shade tree association characteristics (in blue). Only the tree characteristics and soil functions selected in the models from Table 4 were used to build the RDA. \%N, P, K, Ca, Mg: leaf litter N, P, K, Ca, Mg content. 


\section{Tables}

TABLE 1 Shade tree and cocoa characteristics.

\begin{tabular}{|c|c|c|c|c|c|c|}
\hline \multirow[b]{3}{*}{ Tree characteristics } & \multirow{2}{*}{$\begin{array}{c}\text { Reference } \\
\text { Сосоа }\end{array}$} & \multicolumn{5}{|c|}{ Shade tree species } \\
\hline & & Canarium & Dacryodes & Milicia & Ceiba & Albizia \\
\hline & & & & & & \\
\hline Succession guild & Shade tolerant & Pioneer & Pioneer & Pioneer & Pioneer & $\begin{array}{l}\text { Non-pioneer light } \\
\text { demander }\end{array}$ \\
\hline Leaf habit & Semi-deciduous & Evergreen & Evergreen & Deciduous & Deciduous & Deciduous \\
\hline Legume vs non-legume & Non-legume & Non-legume & Non-legume & Non-legume & Non-legume & Legume \\
\hline Height (m) & $6 \pm 0 \mathrm{c}$ & $29 \pm 2 a$ & $12 \pm 3 b$ & $31 \pm 4 a$ & $31 \pm 4 a$ & $17 \pm 9 \mathrm{~b}$ \\
\hline $\mathrm{DBH}(\mathrm{cm})$ & $13 \pm 4 d$ & $119 \pm 27 b$ & $36 \pm 14 \mathrm{c}$ & $129 \pm 61 \mathrm{~b}$ & $321 \pm 83$ a & $86 \pm 24 b$ \\
\hline Canopy area $\left(\mathrm{m}^{2}\right)$ & $\mathrm{Na}$ & $446 \pm 211$ a & $102 \pm 65 b$ & $252 \pm 260 \mathrm{ab}$ & $513 \pm 314$ a & $411 \pm 238$ a \\
\hline Leaf $\mathrm{N}$ resorption efficiency (\%) & $51 \pm 3 a b$ & $41 \pm 5 \mathrm{~cd}$ & $53 \pm 1 a$ & $34 \pm 5 d$ & $44 \pm 4 \mathrm{bc}$ & $21 \pm 1$ e \\
\hline Leaf $\mathrm{P}$ resorption efficiency (\%) & $73 \pm 2 a$ & $31 \pm 17 b$ & $44 \pm 6$ ab & $52 \pm 10 a b$ & $38 \pm 10 \mathrm{~b}$ & $36 \pm 19 \mathrm{~b}$ \\
\hline \multicolumn{7}{|l|}{ Leaf litter traits } \\
\hline $\mathrm{N}\left(\mathrm{mg} \cdot \mathrm{g}^{-1} \mathrm{DM}\right)$ & $10.5 \pm 0.5 \mathrm{~cd}$ & $9.6 \pm 0.8 \mathrm{~d}$ & $12.2 \pm 1.2 \mathrm{bcd}$ & $15.1 \pm 4.6 \mathrm{bc}$ & $16.1 \pm 0.7 \mathrm{~b}$ & $30.2 \pm 6.8 \mathrm{a}$ \\
\hline$P\left(m g \cdot g^{-1} \mathrm{DM}\right)$ & $0.6 \pm 0.1 \mathrm{c}$ & $0.8 \pm 0.2 \mathrm{bc}$ & $1.0 \pm 0.2 \mathrm{abc}$ & $1.0 \pm 0.1 \mathrm{abc}$ & $1.3 \pm 0.2 \mathrm{a}$ & $1.2 \pm 0.5 a b$ \\
\hline $\mathrm{K}\left(\mathrm{mg} \cdot \mathrm{g}^{-1} \mathrm{DM}\right)$ & $5.8 \pm 1.2 \mathrm{~b}$ & $5.2 \pm 0.5 b$ & $7.4 \pm 0.3 b$ & $14.2 \pm 5.9 \mathrm{a}$ & $5.9 \pm 0.9 b$ & $6.9 \pm 2.1 \mathrm{~b}$ \\
\hline $\mathrm{Ca}\left(\mathrm{mg} \cdot \mathrm{g}^{-1} \mathrm{DM}\right)$ & $17.7 \pm 1.7 b$ & $19.9 \pm 3.1 \mathrm{~b}$ & $14.6 \pm 1.9 b$ & $18.2 \pm 4.4 \mathrm{~b}$ & $32.7 \pm 5.0 \mathrm{a}$ & $15.4 \pm 1.7 \mathrm{~b}$ \\
\hline $\mathrm{Mg}\left(\mathrm{mg} \cdot \mathrm{g}^{-1} \mathrm{DM}\right)$ & $7.0 \pm 1.8 \mathrm{a}$ & $3.2 \pm 0.8 \mathrm{~cd}$ & $2.7 \pm 0.5 \mathrm{~cd}$ & $4.7 \pm 0.6 \mathrm{bc}$ & $5.1 \pm 0.4 \mathrm{ab}$ & $2.2 \pm 0.3 \mathrm{~d}$ \\
\hline $\mathrm{pH}\left(\mathrm{H}_{2} \mathrm{O}\right)$ & $7.0 \pm 0.0 \mathrm{a}$ & $5.9 \pm 0.3 \mathrm{~b}$ & $4.8 \pm 0.3 \mathrm{c}$ & $7.1 \pm 0.2 \mathrm{a}$ & $7.0 \pm 0.2 \mathrm{a}$ & $6.7 \pm 0.2 \mathrm{a}$ \\
\hline Soluble VS (mg.g-1 DM) & $209 \pm 10 \mathrm{bc}$ & $162 \pm 18 c$ & $280 \pm 27$ a & $224 \pm 34 a b$ & $157 \pm 12 c$ & $77 \pm 33 d$ \\
\hline Cellulose VS (mg.g $\left.\mathrm{g}^{-1} \mathrm{DM}\right)$ & $149 \pm 56 a b$ & $127 \pm 8 b$ & $130 \pm 34 a b$ & $112 \pm 5 b$ & $116 \pm 11 b$ & $195 \pm 23$ a \\
\hline Hemicellulose VS (mg.g $\left.{ }^{-1} \mathrm{DM}\right)$ & $214 \pm 23$ a & $220 \pm 48$ a & $178 \pm 20 \mathrm{a}$ & $236 \pm 53 a$ & $272 \pm 35 a$ & $260 \pm 48$ a \\
\hline Lignin VS (mg.g-1DM) & $428 \pm 46$ a & $491 \pm 43$ a & $412 \pm 42 a$ & $428 \pm 92 a$ & $455 \pm 48$ a & $468 \pm 63$ a \\
\hline Tannin (mg.g-1 DM) & $25 \pm 7 b$ & $127 \pm 17$ a & $47 \pm 13 b$ & $7 \pm 2 c$ & $39 \pm 14 b$ & $6 \pm 4 c$ \\
\hline Lignocellulose Index (LCI) & $54 \pm 6$ a & $59 \pm 5 a$ & $57 \pm 6 a$ & $55 \pm 10$ a & $54 \pm 5 a$ & $51 \pm 5 a$ \\
\hline Lignin : $\mathrm{N}$ ratio & $41 \pm 6$ a & $51 \pm 8 a$ & $34 \pm 5$ a & $32 \pm 18 a b$ & $28 \pm 2 a b$ & $16 \pm 5 b$ \\
\hline
\end{tabular}

Significant differences were tested by GLM followed by Tukey HSD post hoc tests and bear different letters for P-values $<0.05$. VS: van Soest. $\mathrm{LCl}$ represent the proportion of lignin within the cell wall. Shade tree species characteristics are emphasized in bold when different from the reference cocoa. 
TABLE 2 Leaf litterfall and fine root (diameter $<1 \mathrm{~cm}$ ) biomass under the different associations.

\begin{tabular}{|c|c|c|c|c|c|c|}
\hline & \multirow{2}{*}{ Unshaded } & \multicolumn{5}{|c|}{ Under shade trees } \\
\hline & & Canarium & Dacryodes & Milicia & Ceiba & Albizia \\
\hline Cocoa density (plant $100 \mathrm{~m}^{-2}$ ) & $14 \pm 3 \mathrm{ab}$ & $14 \pm 3 \mathrm{ab}$ & $14 \pm 2 \mathrm{ab}$ & $13 \pm 2 \mathrm{ab}$ & $17 \pm 3 a$ & $11 \pm 5 b$ \\
\hline \multicolumn{7}{|l|}{ Fine root biomass $\left(\mathrm{kg} D M \mathrm{~m}^{-2}\right)$} \\
\hline From Cocoa & $0.16 \pm 0.06 \mathrm{a}$ & $0.15 \pm 0.08 \mathrm{a}$ & $0.12 \pm 0.08 \mathrm{a}$ & $0.18 \pm 0.06 \mathrm{a}$ & $0.15 \pm 0.11 \mathrm{a}$ & $0.08 \pm 0.02 \mathrm{a}$ \\
\hline From shade tree & $0.03 \pm 0.04 a$ & $0.02 \pm 0.02 a$ & $0.05 \pm 0.04 \mathrm{a}$ & $0.06 \pm 0.05 a$ & $0.02 \pm 0.03 a$ & $0.03 \pm 0.01 \mathrm{a}$ \\
\hline Total & $0.19 \pm 0.08 \mathrm{a}$ & $0.18 \pm 0.07 \mathrm{a}$ & $0.17 \pm 0.11 \mathrm{a}$ & $0.24 \pm 0.05 \mathrm{a}$ & $0.17 \pm 0.10 \mathrm{a}$ & $0.10 \pm 0.02 \mathrm{a}$ \\
\hline \multicolumn{7}{|l|}{ Leaf litterfall $\left(\mathrm{kg} \mathrm{DM} \mathrm{\textrm {m } ^ { - 2 } )}\right.$} \\
\hline From Cocoa & $0.28 \pm 0.09 \mathrm{a}$ & $0.15 \pm 0.07 \mathrm{~b}$ & $0.13 \pm 0.04 \mathrm{~b}$ & $0.13 \pm 0.08 b$ & $0.15 \pm 0.07 b$ & $0.11 \pm 0.03 b$ \\
\hline From shade tree & $0.02 \pm 0.04 \mathrm{c}$ & $0.26 \pm 0.06 \mathrm{~b}$ & $0.34 \pm 0.14 a b$ & $0.47 \pm 0.17$ a & $0.36 \pm 0.14 a b$ & $0.36 \pm 0.04 a b$ \\
\hline Total & $0.31 \pm 0.08 b$ & $0.41 \pm 0.07 \mathrm{ab}$ & $0.47 \pm 0.13 a$ & $0.60 \pm 0.21 \mathrm{a}$ & $0.51 \pm 0.14 \mathrm{a}$ & $0.46 \pm 0.03 \mathrm{ab}$ \\
\hline
\end{tabular}

Significant differences were tested by GLM followed by Tukey HSD post hoc tests and bear different letters for $P$-values $<0.05$. Values under shade tree species are emphasized in bold when different from the unshaded treatment. 
TABLE 3 Soil functions under the different associations.

\begin{tabular}{|c|c|c|c|c|c|c|}
\hline & \multirow{2}{*}{ Unshaded } & \multicolumn{5}{|c|}{ Under shade trees } \\
\hline & & Canarium & Dacryodes & Milicia & Ceiba & Albizia \\
\hline Soil C ( $g C k^{-1}$ soil) & $15.4 \pm 5.3 b$ & $17.8 \pm 5.0 \mathrm{ab}$ & $16.8 \pm 6.5 \mathrm{ab}$ & $18.9 \pm 3.9 a b$ & $23.5 \pm 5.5 \mathrm{a}$ & $13.9 \pm 2.8 \mathrm{ab}$ \\
\hline Soil $\mathbf{N}$ ( $g N k^{-1}$ soil) & $1.2 \pm 0.4 b$ & $1.4 \pm 0.4 \mathrm{ab}$ & $1.2 \pm 0.4 b$ & $1.5 \pm 0.3 \mathrm{ab}$ & $1.9 \pm 0.5 \mathrm{a}$ & $1.1 \pm 0.2 b$ \\
\hline $\mathrm{NH}_{4}{ }^{+}\left(m g N \mathrm{~kg}^{-1}\right.$ soil $)$ & $4.6 \pm 3.0 \mathrm{~b}$ & $2.2 \pm 0.8 b$ & $2.6 \pm 0.9 b$ & $2.7 \pm 1.0 \mathrm{~b}$ & $2.6 \pm 0.9 b$ & $9.6 \pm 4.0 \mathrm{a}$ \\
\hline $\mathrm{NO}_{3}^{-}\left(\mathrm{mg} \mathrm{N} \mathrm{kg}^{-1}\right.$ soil $)$ & $6.1 \pm 1.6 \mathrm{c}$ & $7.0 \pm 1.2 \mathrm{abc}$ & $7.1 \pm 2.3 \mathrm{bc}$ & $10.9 \pm 1.9 \mathrm{a}$ & $10.5 \pm 3.1 \mathrm{a}$ & $10.5 \pm 3.6 \mathrm{ab}$ \\
\hline Olsen $\mathbf{P}$ (mg $P k^{-1}$ soil) & $9.3 \pm 5.3 b$ & $10.9 \pm 2.1 \mathrm{ab}$ & $14.4 \pm 5.7 \mathrm{ab}$ & $17.2 \pm 5.7 \mathrm{a}$ & $18.7 \pm 7.2$ a & $21.0 \pm 10.6$ a \\
\hline $\mathrm{pH} \mathrm{H} \mathrm{H}_{2} \mathrm{O}$ & $6.6 \pm 0.1 \mathrm{~b}$ & $6.7 \pm 0.1 \mathrm{~b}$ & $6.6 \pm 0.1 \mathrm{~b}$ & $7.1 \pm 0.2 \mathrm{a}$ & $7.2 \pm 0.1 \mathrm{a}$ & $6.0 \pm 0.3 \mathrm{c}$ \\
\hline Bioassay (g DM produced per plant) & $1.5 \pm 0.6 b$ & $1.3 \pm 0.5 b$ & $1.8 \pm 0.6 b$ & $2.1 \pm 0.5 \mathrm{ab}$ & $2.7 \pm 0.8 a$ & $2.1 \pm 0.4 \mathrm{ab}$ \\
\hline Cocoa yield ( $n b$ pods per tree) & $22 \pm 7$ a & $26 \pm 9$ a & $21 \pm 5$ a & $24 \pm 11$ a & $22 \pm 6$ a & $25 \pm 16$ a \\
\hline $\begin{array}{l}\text { C mineralization }\left(m g C \mathrm{~kg}^{-1} \text { soil } \mathrm{d}^{-1}\right) \\
\text { Nitrification }\left(\mathrm{mg} \mathrm{N} \mathrm{kg}^{-1} \mathrm{soil}^{-1}\right)\end{array}$ & $\begin{array}{c}17.7 \pm 7.8 \mathrm{a} \\
1.7 \pm 0.7 \mathrm{a}\end{array}$ & $\begin{array}{l}22.2 \pm 15.1 \mathrm{a} \\
2.4 \pm 1.4 \mathrm{a}\end{array}$ & $\begin{array}{l}8.2 \pm 5.5 \mathrm{a} \\
1.3 \pm 0.6 \mathrm{a}\end{array}$ & $\begin{array}{c}11.8 \pm 5.8 \mathrm{ab} \\
1.3 \pm 0.6 \mathrm{a}\end{array}$ & $\begin{array}{c}16.5 \pm 7.7 \mathrm{a} \\
2.0 \pm 0.5 \mathrm{a}\end{array}$ & $\begin{array}{c}13.7 \pm 5.4 \mathrm{a} \\
1.4 \pm 0.1 \mathrm{a}\end{array}$ \\
\hline
\end{tabular}

Significant differences were tested by GLM followed by Tukey HSD post hoc tests and bear different letters for P-values $<0.05$. Values under shading are emphasized in bold when different from unshaded treatment. 
TABLE 4 Model averaging of soil functions by cocoa - shade tree association litterfall and community weighted mean litter traits, performed on centered-reduced data. For each function, the relative importance (RI) was estimated for all variables.

\begin{tabular}{|c|c|c|c|c|c|c|c|}
\hline & $\frac{0}{\overline{0}}$ & $\begin{array}{l}z \\
\overline{\bar{o}} \\
\text { க) }\end{array}$ & $\frac{n^{+}}{\mathbf{z}}$ & '̊ & $\begin{array}{l}0 \\
\frac{0}{\Phi} \\
\text { OD } \\
0\end{array}$ & 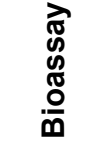 & $\frac{\text { I }}{\frac{2}{\overline{0}}}$ \\
\hline Litterfall & 0.20 & 0.23 & 0.35 & 0.19 & 0.24 & $0.54^{t}$ & 0.26 \\
\hline Soluble & 0.24 & 0.21 & $1.00^{*}$ & 0.47 & 0.39 & 0.22 & 0.21 \\
\hline Tannins & 0.23 & 0.24 & $0.96^{* *}$ & 0.24 & $0.76^{t}$ & 0.51 & 0.38 \\
\hline LCI & 0.24 & 0.26 & 0.37 & 0.22 & 0.22 & 0.21 & 0.27 \\
\hline Litter pH & 0.22 & 0.20 & 0.56 & 0.36 & 0.29 & 0.24 & 0.19 \\
\hline$\% N$ & 0.27 & 0.22 & 0.26 & 0.39 & 0.37 & 0.26 & $0.99^{* * *}$ \\
\hline$\% \mathrm{P}$ & 0.33 & 0.24 & 0.49 & 0.50 & 0.42 & 0.28 & $0.88^{* *}$ \\
\hline$\% \mathrm{~K}$ & 0.20 & 0.21 & 0.29 & 0.72 & 0.25 & 0.29 & $0.99 * * *$ \\
\hline$\% \mathrm{Ca}$ & $0.85^{*}$ & $0.98^{* * *}$ & $0.68^{*}$ & $0.64^{+}$ & 0.48 & $0.96^{* *}$ & $1.00^{* * *}$ \\
\hline$\% M g$ & 0.20 & 0.20 & 0.30 & 0.28 & 0.68 & 0.36 & 0.19 \\
\hline
\end{tabular}

$R I$ varies from 0 to 1 and represents the sum of the Akaike weights of the models in which each variable is used. $R I$ represented in red and blue correspond to significant variables ${ }^{+} P<0.10$; $: P<0.05$; **: $P<$ 0.01 ; ${ }^{* *}: P<0.001$ ) with positive and negative coefficient, respectively (see Table S6 for further details). 
- Unshaded O Canarium O Milicia

- Albizia $\triangle$ Dacryodes $\triangle$ Ceiba
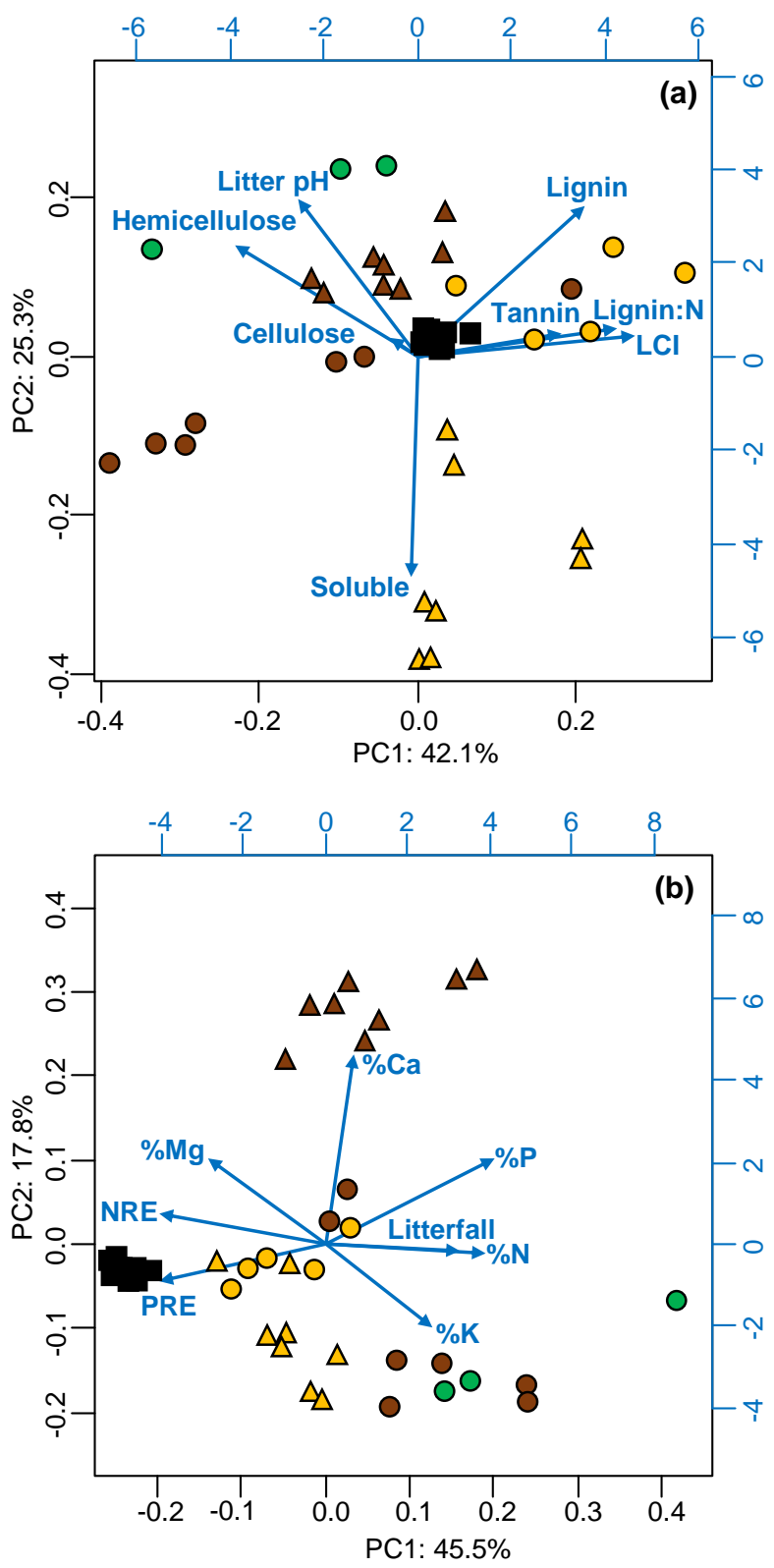

Fig. 1 


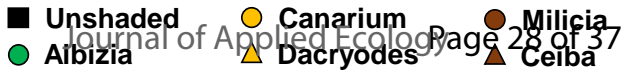

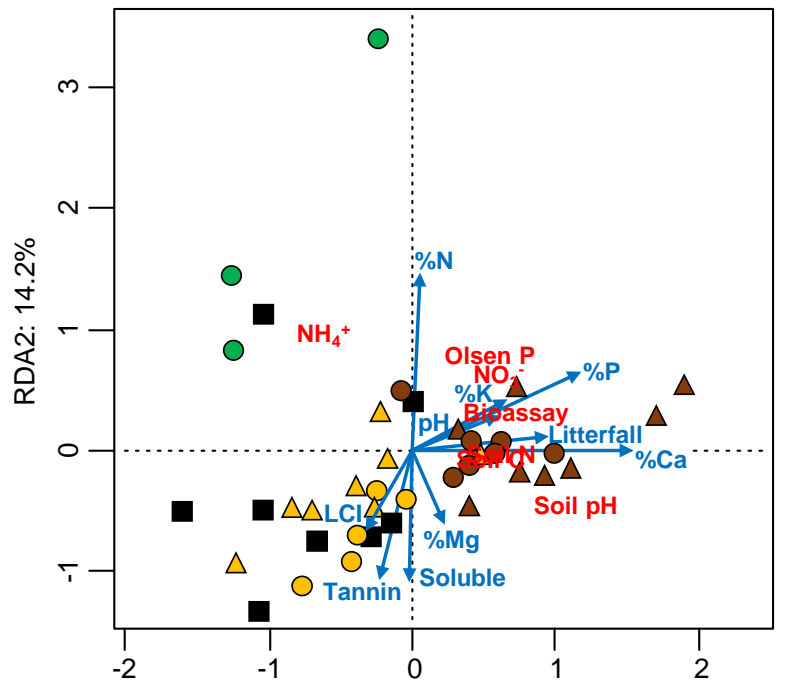

RDA1: $28.4 \%$

\section{Fig. 3}




\section{Supporting Information from Sauvadet et al. (2019)}

TABLE S1 Summary of the experimental design strategy. One soil sampling and litter collectors were set up in $10 \mathrm{~m} \times 10 \mathrm{~m}$ subplot under the canopy of each studied shade trees, excepted under Albizia adianthifolia where two sampling subplots per tree were performed because of the few tree number of this species. The Unshaded treatment refers to sampling subplots under cocoa outside any shade tree canopies.

\begin{tabular}{|c|c|c|c|c|c|c|}
\hline & $\begin{array}{l}\text { Unshaded } \\
\text { cocoa }\end{array}$ & Canarium & Dacryodes & Milicia & Ceiba & Albizia \\
\hline \multicolumn{7}{|c|}{$\begin{array}{c}\text { Number of studied trees / } \\
\text { unshaded plots }\end{array}$} \\
\hline Farm \#1 & 1 & 2 & 1 & 1 & 1 & 1 \\
\hline Farm \#2 & 1 & 1 & 1 & & 1 & \\
\hline Farm \#3 & 1 & & 1 & & 1 & 1 \\
\hline Farm \#4 & 1 & & 1 & & 1 & 1 \\
\hline Farm \#5 & 1 & 1 & 1 & 2 & 1 & \\
\hline Farm \#6 & 1 & & 1 & 1 & 1 & \\
\hline Farm \#7 & 1 & & 1 & 2 & 1 & \\
\hline Farm \#8 & 1 & 1 & 1 & 1 & 1 & \\
\hline Studied trees & na & 5 & 8 & 7 & 8 & 3 \\
\hline Sampling subplots & 8 & 5 & 8 & 7 & 8 & 6 \\
\hline $\begin{array}{l}\text { Litter sample pools for } \\
\text { traits analysis }\end{array}$ & $\begin{array}{c}\text { [Farms \# 1+2]; } \\
{[\text { Farms \# 3+4]; }} \\
{[\text { Farms \# 5+6+7+8] }}\end{array}$ & $\begin{array}{c}\text { [Farm \#1] ; } \\
\text { [Farm \#2]; } \\
\text { [Farm \#5]; } \\
\text { [Farm \#8] }\end{array}$ & $\begin{array}{c}{[\text { [Farms \# 1+2]; }} \\
{[\text { Farms \# 3+4]; }} \\
\text { [Farms \# 5+6+7+8] }\end{array}$ & 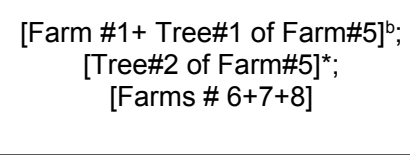 & $\begin{array}{c}\text { [Farms \# 1+2]; } \\
{[\text { Farms \# 3+4]; }} \\
\text { [Farms \# 5+6+7+8] }\end{array}$ & $\begin{array}{l}{[\text { Farm \#1] }} \\
{[\text { Farm \#3] }} \\
{[\text { Farm \#4] }}\end{array}$ \\
\hline
\end{tabular}

a : Canarium litter was not pooled between Farm $\# 1$ and $\# 2$ for traits analysis, because of a pods disposal close to the Farm \#2 Canarium, which may have artificially enriched Canarium leaf $\mathrm{P}$ content; $\mathrm{b}$ : Farm \#1 Milicia tree did not provide enough litter to perform all the analyses, and was thus pooled with Farm \#5 Milicia tree \#1 
TABLE S2 Cocoa - shade tree associations community weighted mean attribute and elemental restitution by litterfall. Under shade tree, each community attribute was averaged between cocoa and shade tree litter traits, relatively to its contribution to litterfall (presented in Table 2). C and nutrient restitution correspond to the sum of nutrient restituted (litterfall $x$ litter nutrient content) by shade tree and cocoa litterfall.

\begin{tabular}{|c|c|c|c|c|c|c|}
\hline & \multirow{2}{*}{ Unshaded } & \multicolumn{5}{|c|}{ Under shade trees } \\
\hline & & Canarium & Dacryodes & Milicia & Ceiba & Albizia \\
\hline \multicolumn{7}{|l|}{ Physiological traits } \\
\hline $\mathrm{N}$ resorption efficiency (\%) & $51 \pm 0$ a & $45 \pm 3 b$ & $52 \pm 0 \mathrm{a}$ & $37 \pm 4 c$ & $45 \pm 3 b$ & $28 \pm 1 d$ \\
\hline P resorption efficiency (\%) & $73 \pm 0$ a & $45 \pm 10 \mathrm{~b}$ & $53 \pm 4 \mathrm{~b}$ & $53 \pm 7 \mathrm{~b}$ & $47 \pm 8 \mathrm{~b}$ & $44 \pm 15 b$ \\
\hline \multicolumn{7}{|l|}{ Litter traits } \\
\hline $\mathrm{N}\left(\mathrm{mg} \cdot \mathrm{g}^{-1} \mathrm{DM}\right)$ & $10.5 \pm 0.0 \mathrm{~d}$ & $9.9 \pm 0.5 \mathrm{~d}$ & $12.0 \pm 0.8 \mathrm{~cd}$ & $15.4 \pm 2.6 \mathrm{~b}$ & $14.3 \pm 1.0 \mathrm{bc}$ & $25.8 \pm 5.7 \mathrm{a}$ \\
\hline$P\left(m g \cdot g^{-1} D M\right)$ & $0.6 \pm 0.0 \mathrm{c}$ & $0.7 \pm 0.1 \mathrm{bc}$ & $0.8 \pm 0.1 \mathrm{ab}$ & $0.9 \pm 0.1 \mathrm{a}$ & $1.1 \pm 0.1 \mathrm{a}$ & $1.0 \pm 0.4 \mathrm{a}$ \\
\hline $\mathrm{K}\left(\mathrm{mg} \cdot \mathrm{g}^{-1} \mathrm{DM}\right)$ & $5.4 \pm 0.1 \mathrm{~b}$ & $5.3 \pm 0.3 b$ & $6.7 \pm 0.2 b$ & $13.8 \pm 4.6 \mathrm{a}$ & $5.8 \pm 0.4 \mathrm{~b}$ & $6.5 \pm 1.7 \mathrm{~b}$ \\
\hline $\mathrm{Ca}\left(\mathrm{mg} \cdot \mathrm{g}^{-1} \mathrm{DM}\right)$ & $17.3 \pm 0.1 \mathrm{bc}$ & $18.7 \pm 2.1 \mathrm{~b}$ & $15.3 \pm 1.2 \mathrm{c}$ & $18.5 \pm 2.5 b$ & $26.8 \pm 1.7 \mathrm{a}$ & $15.8 \pm 1.3 \mathrm{bc}$ \\
\hline $\mathrm{Mg}\left(\mathrm{mg} \cdot \mathrm{g}^{-1} \mathrm{DM}\right)$ & $7.2 \pm 0.1 \mathrm{a}$ & $4.7 \pm 0.8 \mathrm{c}$ & $4.0 \pm 0.8 \mathrm{~cd}$ & $5.3 \pm 0.4 \mathrm{bc}$ & $5.9 \pm 0.3 \mathrm{~b}$ & $3.3 \pm 0.3 \mathrm{~d}$ \\
\hline $\mathrm{pH}\left(\mathrm{H}_{2} \mathrm{O}\right)$ & $7.0 \pm 0.0 \mathrm{a}$ & $6.3 \pm 0.2 \mathrm{~b}$ & $5.4 \pm 0.4 \mathrm{c}$ & $7.2 \pm 0.2 \mathrm{a}$ & $7.0 \pm 0.1 \mathrm{a}$ & $6.7 \pm 0.2 \mathrm{a}$ \\
\hline Soluble VS (mg.g-1 DM) & $209 \pm 0 \mathrm{~b}$ & $181 \pm 16 \mathrm{c}$ & $265 \pm 23$ a & $233 \pm 23 b$ & $176 \pm 10 \mathrm{c}$ & $108 \pm 22 d$ \\
\hline Cellulose VS (mg.g $\left.\mathrm{g}^{-1} \mathrm{DM}\right)$ & $140 \pm 3 b$ & $133 \pm 5 \mathrm{bc}$ & $137 \pm 23 \mathrm{bc}$ & $120 \pm 5 c$ & $121 \pm 9 \mathrm{c}$ & $182 \pm 15$ a \\
\hline Hemicellulose VS (mg.g $\left.{ }^{-1} \mathrm{DM}\right)$ & $209 \pm 2 b$ & $214 \pm 28 b$ & $184 \pm 14 \mathrm{c}$ & $248 \pm 33$ a & $251 \pm 14$ a & $249 \pm 38 a b$ \\
\hline Lignin VS (mg.g-1 DM) & $442 \pm 5 a b$ & $473 \pm 28 a$ & $413 \pm 29 b$ & $399 \pm 59 b$ & $452 \pm 25 a$ & $461 \pm 50 \mathrm{ab}$ \\
\hline Tannin (mg.g $\left.\mathrm{g}^{-1} \mathrm{DM}\right)$ & $26 \pm 0 c$ & $90 \pm 16$ a & $38 \pm 5 \mathrm{~b}$ & $12 \pm 3 d$ & $38 \pm 10 \mathrm{~b}$ & $11 \pm 2 d$ \\
\hline Lignocellulose Index (LCI) & $56 \pm 1$ a & $58 \pm 3 a$ & $56 \pm 4 \mathrm{a}$ & $52 \pm 6 a$ & $55 \pm 2 a$ & $52 \pm 4 \mathrm{a}$ \\
\hline Lignin : $\mathrm{N}$ ratio & $42 \pm 1 a b$ & $48 \pm 5 a$ & $35 \pm 4 \mathrm{bc}$ & $29 \pm 10 \mathrm{~cd}$ & $33 \pm 1 \mathrm{c}$ & $22 \pm 5 d$ \\
\hline \multicolumn{7}{|l|}{$\begin{array}{l}\text { Elemental restitution by } \\
\text { litterfall }\end{array}$} \\
\hline $\mathrm{C}\left(\mathrm{kg} \mathrm{m}^{-2}\right)$ & $0.13 \pm 0.00 \mathrm{e}$ & $0.19 \pm 0.00 \mathrm{~d}$ & $0.22 \pm 0.00 \mathrm{c}$ & $0.26 \pm 0.01 \mathrm{a}$ & $0.24 \pm 0.00 \mathrm{~b}$ & $0.23 \pm 0.00 \mathrm{bc}$ \\
\hline $\mathrm{N}\left(g m^{-2}\right)$ & $3.3 \pm 0.1 \mathrm{f}$ & $4.1 \pm 0.2 \mathrm{e}$ & $5.6 \pm 0.3 \mathrm{~d}$ & $9.2 \pm 1.4 \mathrm{~b}$ & $7.4 \pm 0.2 \mathrm{c}$ & $11.9 \pm 2.5 \mathrm{a}$ \\
\hline $\mathrm{P}\left(g m^{-2}\right)$ & $0.18 \pm 0.03 d$ & $0.28 \pm 0.04 \mathrm{c}$ & $0.40 \pm 0.06 \mathrm{~b}$ & $0.54 \pm 0.02 a$ & $0.56 \pm 0.03 a$ & $0.47 \pm 0.16 a b$ \\
\hline $\mathrm{K}\left(g^{-2}\right)$ & $1.7 \pm 0.3 c$ & $2.2 \pm 0.2 \mathrm{c}$ & $3.2 \pm 0.2 \mathrm{~b}$ & $8.2 \pm 2.6 \mathrm{a}$ & $3.0 \pm 0.3 \mathrm{bc}$ & $3.1 \pm 0.9 \mathrm{~b}$ \\
\hline $\mathrm{Ca}\left(g m^{-2}\right)$ & $5.5 \pm 0.2 \mathrm{~d}$ & $7.6 \pm 0.9 \mathrm{c}$ & $7.3 \pm 0.4 \mathrm{c}$ & $11.0 \pm 1.4 \mathrm{~b}$ & $14.0 \pm 1.7 \mathrm{a}$ & $7.4 \pm 0.4 \mathrm{c}$ \\
\hline $\operatorname{Mg}\left(g m^{-2}\right)$ & $2.1 \pm 0.4 b$ & $2.0 \pm 0.4 \mathrm{~b}$ & $1.9 \pm 0.3 b$ & $3.2 \pm 0.3 a$ & $3.0 \pm 0.3 a$ & $1.5 \pm 0.1 \mathrm{c}$ \\
\hline
\end{tabular}


TABLE S3 Linear mixed-effects models of farms identity impacts on cocoa - shade tree associations community weighted mean attributes, with associations identity set as random effects. The analyses were performed on the treatments represented by one modality per farm (i.e. unshaded cocoa, cocoa Dacryodes edulis and cocoa - Ceiba pentandra associations).

\begin{tabular}{ll}
\hline $\begin{array}{c}\text { Degree of } \\
\text { freedom }\end{array}$ F-value P-value \\
\hline
\end{tabular}

\section{Physiological traits}

$\mathrm{N}$ resorption efficiency $(\%)$

$\mathrm{P}$ resorption efficiency (\%)

$\begin{array}{lll}7 & 0.76 & 0.63 \\ 7 & 2.30 & 0.09\end{array}$

\section{Litter traits}

$\mathrm{N}\left(\mathrm{mg} \cdot \mathrm{g}^{-1} \mathrm{DM}\right)$
$\mathrm{P}\left(\mathrm{mg} \cdot \mathrm{g}^{-1} \mathrm{DM}\right)$
$\mathrm{K}\left(\mathrm{mg} \cdot \mathrm{g}^{-1} \mathrm{DM}\right)$
$\mathrm{Ca}\left(\mathrm{mg} \cdot \mathrm{g}^{-1} \mathrm{DM}\right)$
$\mathrm{Mg}\left(\mathrm{mg} \cdot \mathrm{g}^{-1} \mathrm{DM}\right)$
$\mathrm{pH}\left(\mathrm{H}_{2} \mathrm{O}\right)$
Soluble VS (mg.g-1 DM)
Cellulose VS (mg.g-11DM)
Hemicellulose VS (mg.g-1 DM)
Lignin VS (mg.g-1 DM)
Tannin (mg.g $\left.{ }^{-1} \mathrm{DM}\right)$
Lignocellulose Index (LCI)
Lignin : N ratio

7

$\begin{array}{ll}0.46 & 0.85 \\ 0.57 & 0.77 \\ 1.49 & 0.25 \\ 0.87 & 0.55 \\ 0.49 & 0.83 \\ 1.04 & 0.45\end{array}$

$\begin{array}{lll}7 & 0.19 & 0.98\end{array}$

Elemental restitution by litterfall

\begin{tabular}{llcc}
$\mathrm{C}\left(\mathrm{kg} \mathrm{m}^{-2}\right)$ & 7 & 3.82 & 0.02 \\
$\mathrm{~N}\left(\mathrm{~g} \mathrm{~m}^{-2}\right)$ & 7 & 0.20 & 0.98 \\
$\mathrm{P}\left(\mathrm{g} \mathrm{m}^{-2}\right)$ & 7 & 0.63 & 0.73 \\
$\mathrm{~K}\left(\mathrm{~g} \mathrm{~m}^{-2}\right)$ & 7 & 6.83 & 0.001 \\
$\mathrm{Ca}\left(\mathrm{g} \mathrm{m}^{-2}\right)$ & 7 & 1.45 & 0.26 \\
$\mathrm{Mg}\left(\mathrm{g} \mathrm{m}^{-2}\right)$ & 7 & 17.02 & $<0.001$ \\
\hline
\end{tabular}


TABLE S4 Linear mixed-effects models of farms identity impacts on soil functions, with cocoa - shade tree associations identity set as random effects. The analyses were performed on the treatments represented by one modality per farm (i.e. unshaded cocoa, cocoa - Dacryodes edulis and cocoa Ceiba pentandra associations).

\begin{tabular}{|c|c|c|c|}
\hline & $\begin{array}{l}\text { Degree of } \\
\text { freedom }\end{array}$ & F-value & P-value \\
\hline Soil C ( $\mathrm{C}$ kg $\mathrm{kg}^{-1}$ soil) & 7 & 0.57 & 0.77 \\
\hline Soil $\mathbf{N}\left(g N k g^{-1}\right.$ soil) & 7 & 0.57 & 0.77 \\
\hline $\mathbf{N H}_{4}{ }^{+}\left(m g N k^{-1}\right.$ soil $)$ & 7 & 1.27 & 0.33 \\
\hline $\mathrm{NO}_{3}^{-}\left(m g N \mathrm{~kg}^{-1}\right.$ soil $)$ & 7 & 0.59 & 0.75 \\
\hline Olsen $\mathbf{P}$ (mg P kg-1 soil) & 7 & 1.17 & 0.38 \\
\hline $\mathrm{pH} \mathrm{H} \mathrm{H}_{2} \mathrm{O}$ & 7 & 1.77 & 0.17 \\
\hline $\begin{array}{l}\text { Bioassay (g DM produced per plant) } \\
\text { Cocoa yield ( } \mathrm{nb} \text { pods per tree) }\end{array}$ & $\begin{array}{l}7 \\
7\end{array}$ & $\begin{array}{l}2.51 \\
2.92\end{array}$ & $\begin{array}{l}0.07 \\
0.04\end{array}$ \\
\hline $\begin{array}{l}\text { C mineralization }\left(m g C \mathrm{~kg}^{-1} \text { soil } \mathrm{d}^{-1}\right) \\
\text { Nitrification }\left(m g N \mathrm{~kg}^{-1} \text { soil }^{-1}\right)\end{array}$ & $\begin{array}{l}7 \\
7\end{array}$ & $\begin{array}{l}0.92 \\
0.55\end{array}$ & $\begin{array}{l}0.52 \\
0.78\end{array}$ \\
\hline
\end{tabular}


FIGURE S1 Values of the standardized soil functions under each cocoa - shade tree associations. Each function was standardized by expressing them as a percentage of the maximum values observed across all plots. As such, $100 \%$ correspond to one single plot and treatments do not necessarily show value up to $100 \%$.

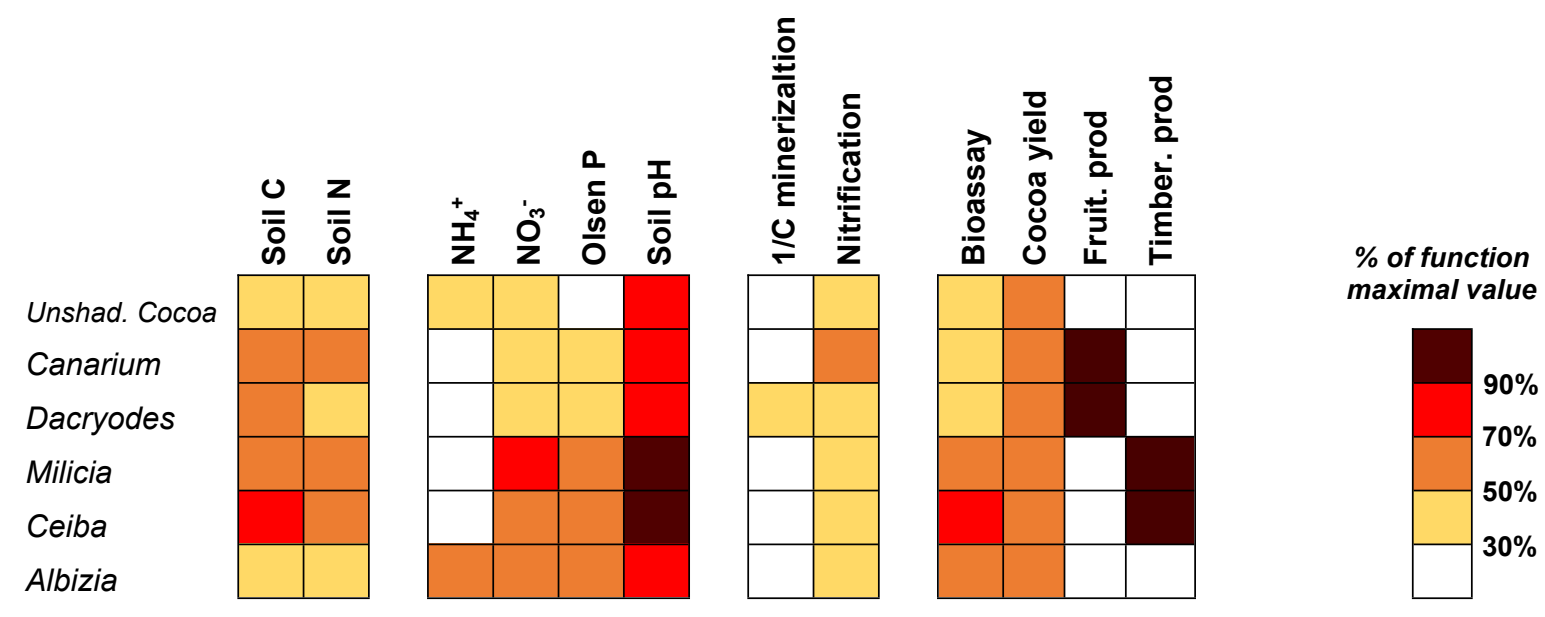


FIGURE S2 Cocoa - Shade tree associations characteristics (on the left) and soil functions (on the right) Pearson correlation coefficient matrices ( $\mathrm{n}=42$ ). Correlations were corrected for multiple comparisons with the Benjamini-Hochberg method. Significance correlations: ${ }^{*} \mathrm{P}$-values $<0.05$; ${ }^{* *} \mathrm{P}$-values $<0.01$; ${ }^{* *}$ P-values < 0.001. NRE: N nutrient resorption Efficiency; PRE: P nutrient resorption Efficiency; LCl: proportion of lignin in litter cell wall (lignin / [lignin+ cellulose+hemicellulose]).

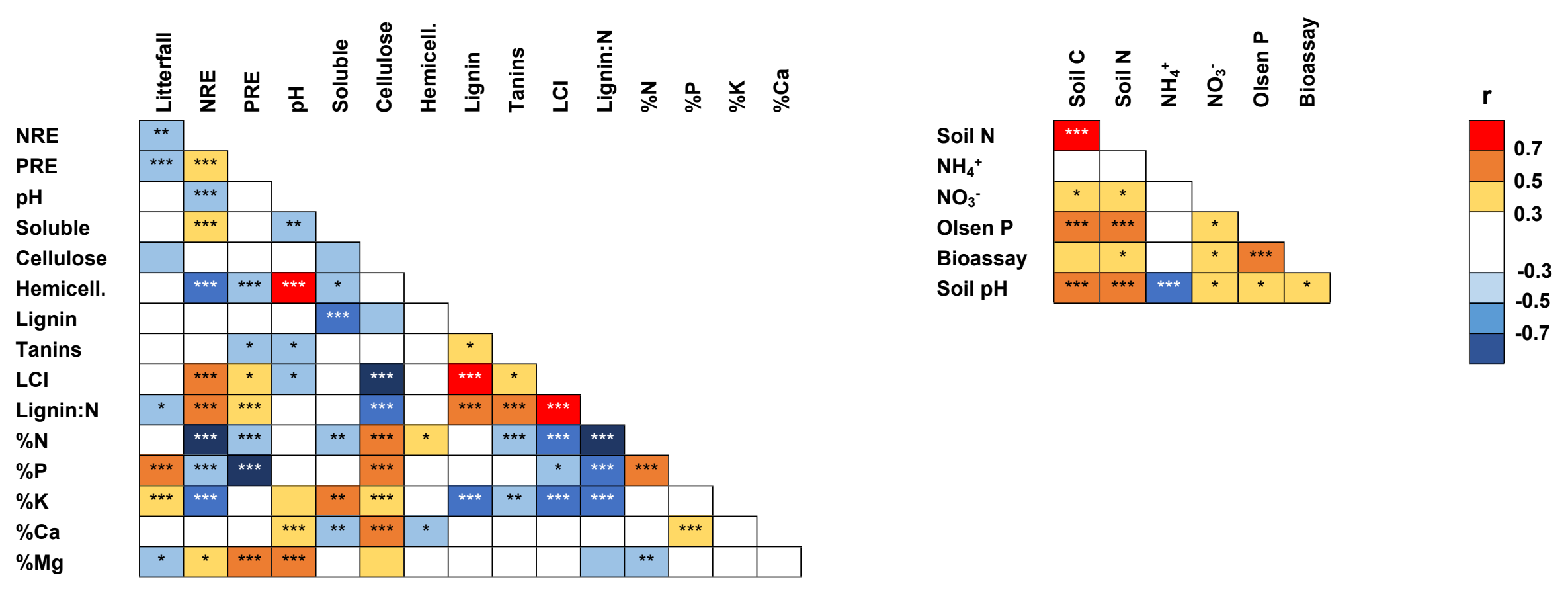


TABLE S5 Pearson correlation coefficient matrix between cocoa - Shade tree associations characteristics and soil functions $(n=42)$.

\begin{tabular}{|c|c|c|c|c|c|c|c|}
\hline & $\frac{\cup}{\overline{\bar{o}}}$ & $\begin{array}{l}\mathbf{z} \\
\overline{\bar{o}} \\
\text { கे }\end{array}$ & 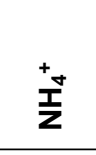 & '̊n & $\begin{array}{l}0 \\
\frac{1}{\Phi} \\
\stackrel{D}{0} \\
0\end{array}$ & $\frac{\text { T }}{\frac{2}{2}}$ & 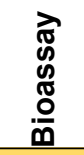 \\
\hline Litterfall & 0.12 & 0.14 & -0.26 & 0.26 & 0.28 & 0.35 & 0.38 \\
\hline Soluble & -0.04 & -0.14 & $-0.46^{*}$ & -0.24 & -0.17 & 0.15 & -0.08 \\
\hline Tannins & -0.02 & -0.04 & -0.33 & -0.26 & -0.30 & 0.03 & -0.22 \\
\hline LCI & 0.06 & 0.04 & -0.11 & -0.35 & -0.16 & -0.08 & -0.23 \\
\hline Litter pH & 0.10 & 0.23 & 0.14 & 0.33 & 0.06 & 0.33 & 0.17 \\
\hline$\% \mathrm{~N}$ & -0.05 & -0.01 & $0.40^{*}$ & $0.42^{*}$ & 0.32 & -0.26 & 0.27 \\
\hline$\% P$ & 0.26 & 0.28 & -0.11 & $0.48^{* *}$ & 0.38 & 0.32 & $0.46^{*}$ \\
\hline$\% \mathrm{~K}$ & -0.03 & -0.03 & -0.11 & 0.36 & 0.20 & 0.30 & 0.21 \\
\hline$\% \mathrm{Ca}$ & $0.42^{*}$ & $0.51^{* *}$ & -0.21 & 0.35 & 0.18 & $0.66^{* * *}$ & $0.45^{*}$ \\
\hline$\% \mathrm{Mg}$ & 0.10 & 0.17 & -0.07 & -0.06 & -0.27 & 0.30 & -0.09 \\
\hline
\end{tabular}

Correlations were corrected for multiple comparison with the Benjamini-Hochberg method. Significance correlations:

${ }^{*} P$-values $<0.05 ;{ }^{* \star} P$-values $<0.01 ;{ }^{* \star *} P$-values $<0.001$. LCl: proportion of lignin in litter cell wall (lignin / [lignin+ cellulose+hemicellulose]). 
TABLE S6 Variables coefficients from model averaging of soil functions by cocoa - shade tree association litterfall and community weighted mean litter traits. For each function, the parameter estimates of each variable have been averaged on the models selected on Akaike information criterion (for delta $<2$ ). Models were performed on centered-reduced data.

\begin{tabular}{|c|c|c|c|c|c|c|c|}
\hline & $\frac{0}{\overline{0}}$ & $\begin{array}{l}\mathbf{z} \\
\overline{\bar{o}}\end{array}$ & $\frac{+T^{+}}{\mathbf{Y}}$ & @̊ & $\begin{array}{l}0 \\
\frac{0}{\Phi} \\
\stackrel{\leftrightarrow}{0} \\
0\end{array}$ & 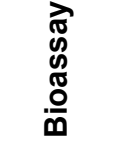 & $\frac{\frac{x}{2}}{\overline{0}}$ \\
\hline Litterfall & 0.06 & 0.10 & -0.19 & 0.00 & 0.14 & $0.28^{t}$ & 0.10 \\
\hline Soluble & 0.12 & 0.07 & $-0.81^{*}$ & -0.44 & -0.36 & 0.10 & 0.10 \\
\hline Tannins & -0.11 & -0.12 & $-0.46^{\star *}$ & -0.14 & $-0.45^{t}$ & -0.27 & -0.13 \\
\hline LCI & 0.14 & 0.14 & -0.23 & -0.06 & -0.14 & -0.09 & 0.13 \\
\hline Litter pH & -0.08 & 0.01 & -0.62 & -0.26 & 0.01 & -0.11 & -0.03 \\
\hline$\% \mathrm{~N}$ & -0.19 & -0.08 & 0.06 & 0.27 & -0.38 & 0.12 & $-0.60^{* * *}$ \\
\hline$\% \mathrm{P}$ & 0.25 & 0.14 & -0.30 & 0.32 & 0.30 & 0.20 & $0.31^{* *}$ \\
\hline$\% \mathrm{~K}$ & 0.04 & 0.07 & 0.33 & 0.50 & 0.16 & 0.19 & $0.49^{* * *}$ \\
\hline$\% \mathrm{Ca}$ & $0.43^{*}$ & $0.51^{\star \star * *}$ & $-0.35^{\star}$ & $0.35^{t}$ & 0.30 & $0.49^{* *}$ & $0.66^{* * *}$ \\
\hline$\% \mathbf{M g}$ & 0.02 & 0.04 & 0.30 & 0.23 & -0.48 & -0.24 & 0.03 \\
\hline
\end{tabular}

${ }^{t},{ }^{*},{ }^{* *}$ and ${ }^{* * *}$ stands for traits whose $P$-value $<0.10,0.05,0.01$ and 0.001 , respectively 
